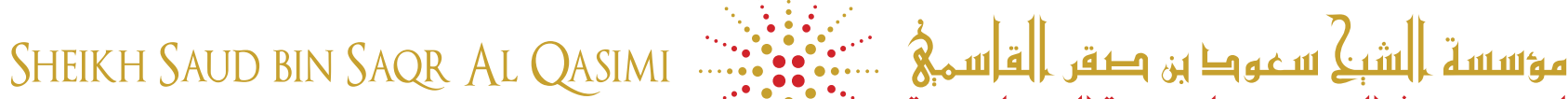
FOUNDATION FOR POLICY RESEARCH

- n

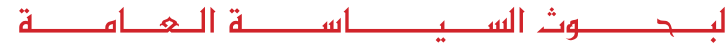

\title{
Education in the
}

United Arab Emirates

and Ras AI Khaimah 


\section{Historical Development of Education in the United Arab Emirates ${ }^{1}$}

The earliest forms of education in today's United Arab Emirates (UAE) were the katateeb, extensions of education in mosques, which focused on Islamic teachings and the basics of reading and writing in the former sheikdoms of the Arabian Gulf2 (AINaqbi, 2009). At this time, students, primarily young boys, were taught by the local mutawa'a, a religious preacher, or the figi, a visiting religious teacher (Ridge, 2009). At the end of the nineteenth century, there was a fundamental shift in education as the region experienced greater wealth following a boom in the local pearling industry.

With the new wealth from pearling, demand for education increased. In 1912, the first private schools in the Trucial States opened in Dubai and Sharjah (Davidson, 2008). These schools were independent initiatives started by pearl traders who had been exposed to modern schools during their travels (AlNaqbi, 2009). By the 1920s, many of the Trucial States had opened schools using curricula and teachers from nearby Arab nations, which began the shift towards the more secular and vocational education that exists today (Alhebsi et al., 2015; Davidson, 2008). However, these early developments were stifled when the pearling industry collapsed in the 1940s (Davidson, 2008).

By the 1950s, the economic situation had improved and schooling began to expand. This was done with the support of Kuwait's Sheikh Abdullah Salem al Sabah, as he sought to develop the Trucial States' education system by providing curricular support and funding for expatriate teachers (Davidson, 2008). The funding from Sheikh Abdullah Salem al Sabah also led to the opening of the country's first modern public school in Sharjah in 1953 (MOE, 2013; Ridge, 2013).

While some schools were funded by Kuwait, additional schools were established by other nations such as Bahrain, Egypt, India, Iran, Saudi Arabia, and Qatar in the 1960s (see Box 1 for an overview of Egypt's impact on the UAE's education system) ${ }^{3}$. Typically, the countries that financially backed the schools also staffed them and used their own texts and curricula. Despite the establishment of several schools during this time period, education was still primarily available to children from privileged backgrounds (Ridge, 2009).

After the formation of the UAE in 1971, the MOE was formally established, creating the first national education system. That same year, His Excellency Sheikh Sultan bin Mohammed Al Qasimi was appointed the first Minister of Education (see Table 1 for a list of all Ministers of Education until 2020). At this time, the newly created MOE began to unify the nation's diverse mix of schools and consolidated 47 schools that had previously been run by Kuwait and other entities (Ridge, 2009; Suliman, 2009). Basic education was also made compulsory for all children (Ridge, 2014). As part of the continued effort to standardize the education system, the MOE launched the country's National Curriculum Project in 1979, and a national curriculum was implemented by 1985 (Ridge, 2009).

\section{Egypt's Impact on the UAE's Education System}

While many different curricula were imported to the UAE in the early days of education, the Egyptian model had the greatest impact on the country's national education system. When the UAE started to modernize its education system in the early 1970s, it did not have an internal model for modern education, so it brought in external educational advisors to counsel the rulers of the emirates. Egyptians were selected for these advisory roles due to Egypt's more established education sector and because their curriculum was perceived to offer a more "localized" education than Western models (Findlow, 2001).

In addition to advisory roles, many Egyptians migrated to the UAE to become teachers. These teachers brought with them teacher-centered approaches to teaching and learning (Davidson, 2008). Historically, many Egyptian teachers came to the Gulf region as contract workers hired through the Egyptian Ministry of Education, but that has since changed. While remnants of the Egyptian curriculum can still be found in the UAE's public education system, it is the enduring presence of Egyptian teachers and their teaching styles that remain most influential (Ridge et al., 2017).

\footnotetext{
1 This section on the historical development of the UAE is largely adopted from Education and the Reverse Gender Divide in the Gulf States: Embracing the Global, Ignoring the Local (Ridge, 2014).

2 The sheikdoms of the Arabian Gulf were later known as the Trucial States and eventually as the United Arab Emirates.

3 Bahgat, 1999; Brooks et al., 2012; Davidson, 2008; Suliman, 2009
} 
Table 1: Ministers of Education in the UAE (1971-Present)

\begin{tabular}{|l|l|}
\hline \multicolumn{1}{|c|}{ Year } & \multicolumn{1}{c}{ Ministers } \\
\hline $1971-1973$ & Sheikh Sultan bin Mohammed Al Qasimi \\
\hline $1973-1979$ & Abdullah bin Omran Traim \\
\hline $1979-1983$ & Saeed Salman \\
\hline $1983-1990$ & Faraj Al Mazrouei \\
\hline $1990-1997$ & Hamad bin Abdulrahman Al Medfa'h \\
\hline $1997-2004$ & Ali Abdul Aziz Al Sharhan \\
\hline $2004-2006$ & Sheikh Nehyan bin Mubarak Al Nahyan \\
\hline $2006-2009$ & Hanif Hasan Ali Al Qasim \\
\hline $2009-2014$ & Humaid Mohammed Obaid Al Qatami \\
\hline $2014-P r e s e n t$ & Hussain Ibrahim Al Hammadi \\
\hline
\end{tabular}

Source: Ridge et al., 2017

Since the UAE's establishment, the continued development of the education system has been a key priority for the government. Considerable investments have been made to address the educational needs of the nation, and many notable transformations have taken place as a result. In 1992, the Ministry of Higher Education and Scientific Research (MOHESR) was established in addition to the MOE to oversee the higher education sector as well as scientific research policies.
In 2016, the structure of the education system changed and the MOHESR was combined with the MOE to now form one Ministry responsible for all levels of education (UAE Government, 2020a). For an overview of the significant creations and mergers of regulatory bodies in the UAE over time, refer to Table 2 .

Currently, the Ministry is served by three Ministers: H.E. Hussain bin Ibrahim Al Hammadi, Minister of Education, H.E. Jameela Bint Salem Mesbeh Al Muhairi, Minister of State for Public Education, and H.E. Dr. Ahmad Bin Abdullah Humaid Belhoul Al Falasi, Minister of State for Higher Education and Advanced Skills. His Excellency Hussain bin Ibrahim Al Hammadi, the 10th Minister of Education, described part of the motivation behind the merger as being to encourage greater cooperation by aligning the "thinking and culture" of schools and higher education institutions (Pennington, 2016).

Over the past decade, enrollment across all school levels has grown continuously, which is highlighted in Figure 1 below. Responding to this trend, the MOE published a Strategic Plan for 2017-2021 under the umbrella of the UAE's larger, national strategy called Vision 2021. The MOE's strategic plan generally focuses on improving higher education and research capacities to create a knowledge-based economy as well as to contribute to achieve the sustainable development goals (MOE, 2020a).

Table 2: Overview of Regulatory Bodies in the UAE

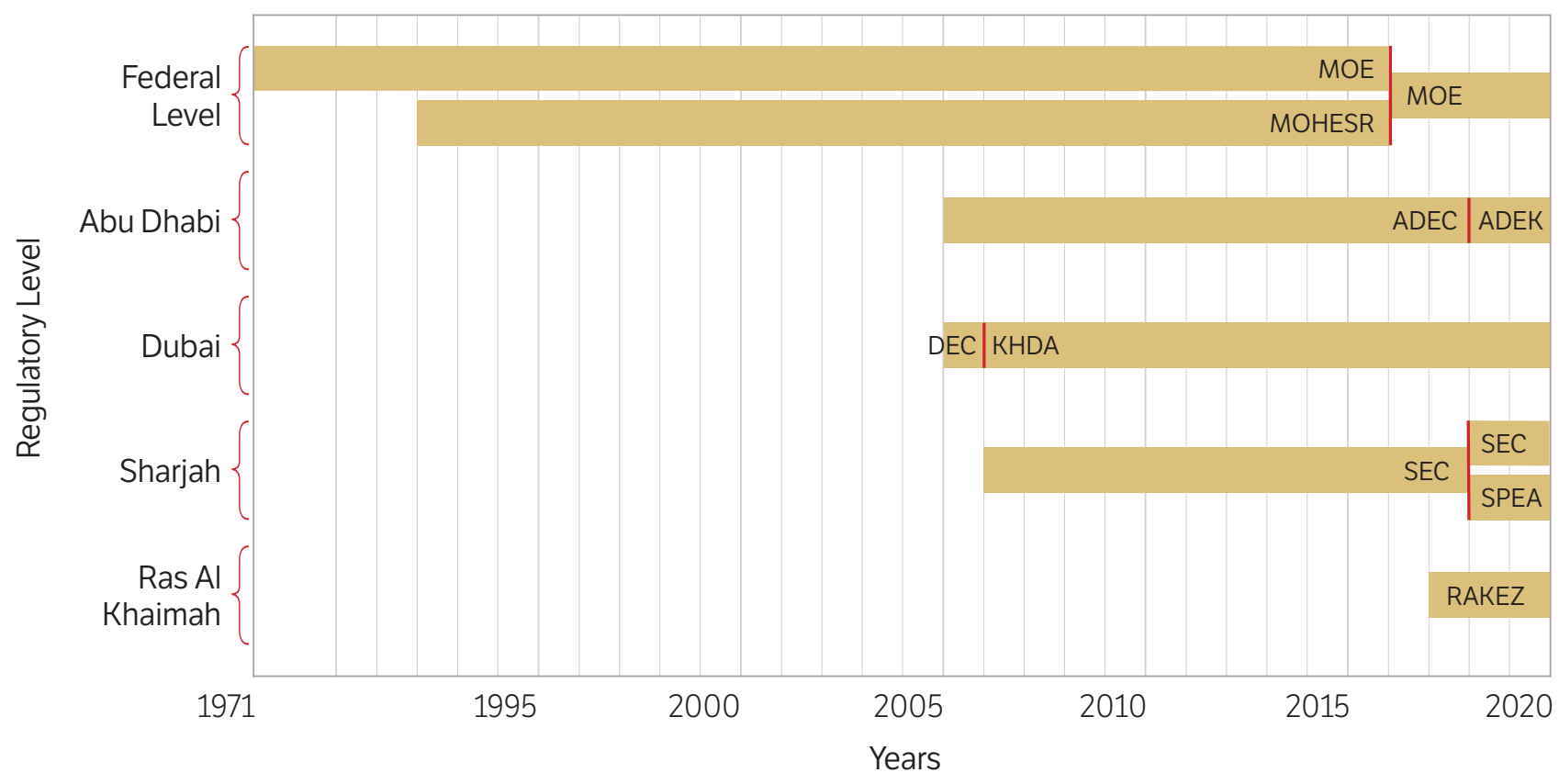

- MOE: Ministry of Education • MOHESR: Ministry of Higher Education and Scientific Research • ADEC: Abu Dhabi Education Council

- ADEK: Abu Dhabi Department of Education and Knowledge • DEC: Dubai Education Council • KHDA: Knowledge and Human Development Authority

- SEC: Sharjah Education Council • SPEA: Sharjah Private Education Authority • RAKEZ: Ras Al Khaimah Economic Zone

- Denotes a merger, renaming, and/or larger reform regarding the respective parties 
Figure 1: Enrollment Rates in the UAE (2013-2017)

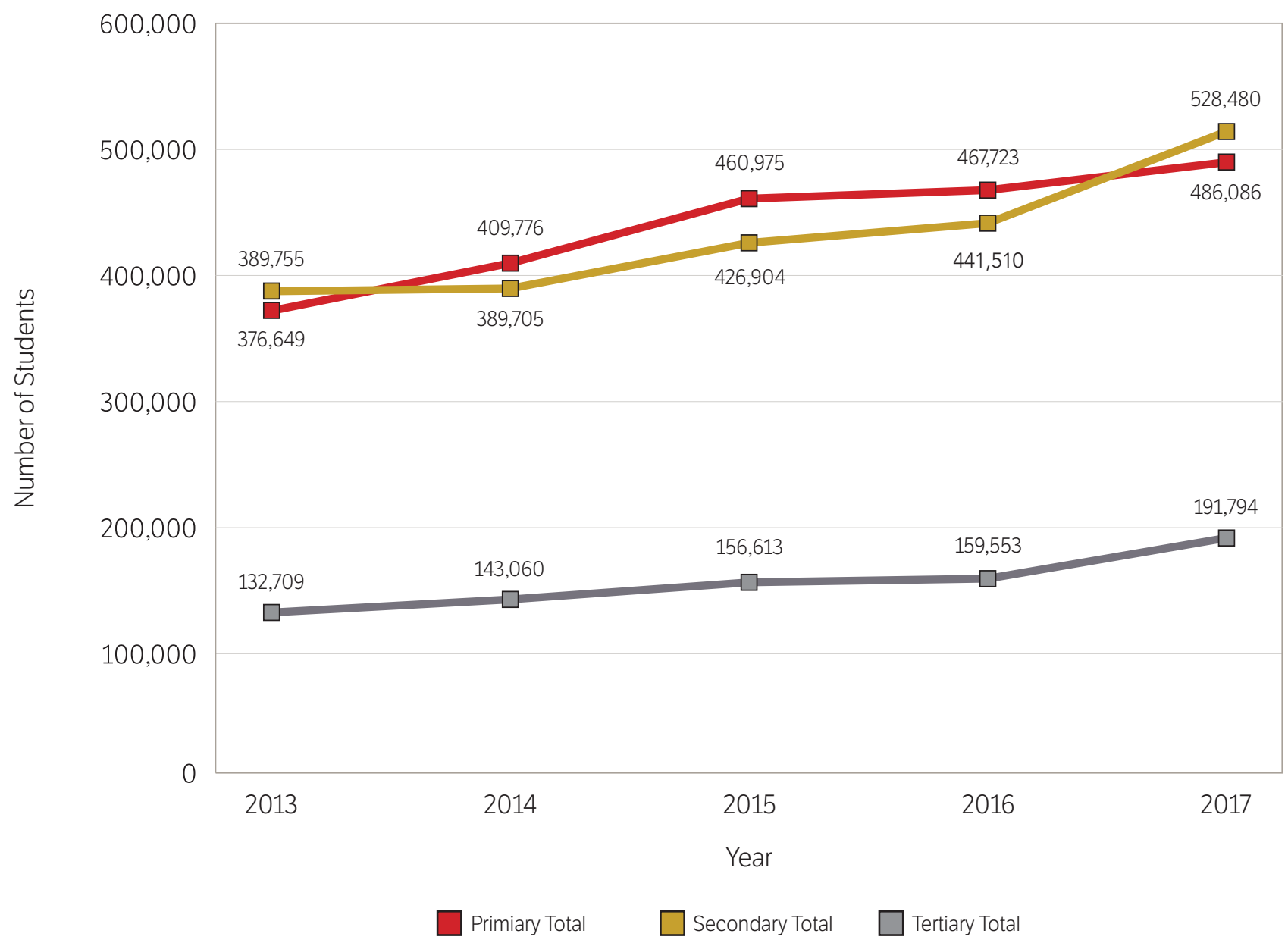

Source: UNESCO Institute of Statistics (UIS), 2020a; MOE, 2018

The K-12 School System in the UAE

The education system in the UAE consists of both a public (government) and a private sector. However, there are also semi-government schools operating in the country (see Appendix A on the Abu Dhabi Centre for Technical \& Vocational Education and Training (ACTVET), and Appendix B on Emirates National Schools). A general trend in the UAE's K-12 system is that the private school sector in the UAE is currently growing at a faster rate than the public sector. In 2010-11, 39\% of schools were private and $61 \%$ were public (MOE, 2011). By the 2018-19 academic year, the percentage of private schools had increased to $49.6 \%$ while the percentage of public schools had decreased to $50.4 \%$. This trend is most pronounced in Dubai, where there are more than two private schools for every public school (see Figure 2). Similar to Dubai, the emirates Sharjah and Ajman also have more private than public schools. In contrast, this trend is reversed in Abu Dhabi and the remaining emirates. While public schools only slightly outnumber private schools in the city of Abu Dhabi, there are between two to four times as many public as private schools in Ras Al Khaimah, Fujairah, and Umm Al Quwain.

Pre-primary education is another area with a noteable trend towards privatization as private providers accounted for about $80 \%$ of enrollment in 2017-2018 (MOE, 2018). Nurseries are licensed through the MOE and offer early childhood education to children from 0-4 years old. Other significant early childhood education entities include Abu Dhabi Early Childhood Authority (ECA), Dubai Early Childhood Development Centre, and The Early Childhood Learning Center (ECLC) of Zayed University (ZU) (UAE Government, 2020b).

The student demographics of public and private schools in the UAE differ substantially. During the 201516 academic year, $82 \%$ (227,000 students) of all UAE public school students were Emirati, with the majority of 
Figure 2: School Types Across the UAE, by Region (2018-2019)

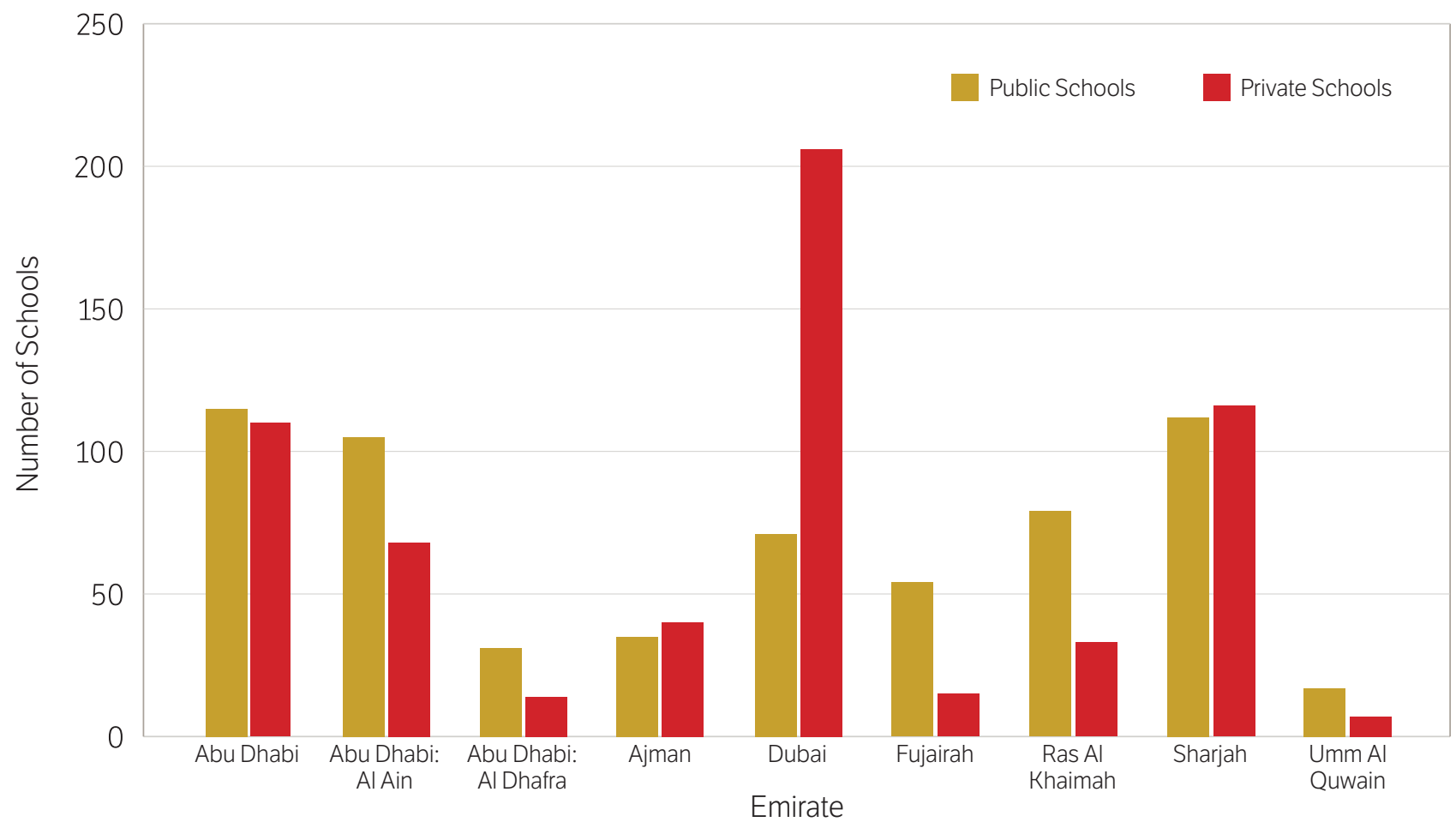

Source: Federal Competitiveness and Statistics Authority (FCSA), 2019a

the remaining $18 \%$ (50,500 students) in public schools largely being comprised of expatriate Arab nationals (or non-Emirati, see Figure 3). This is primarily due to Arabic being the language of instruction in public schools (UAE Government, 2020c).

Although Emiratis comprise the majority of public school students, a more recent trend is that they are increasingly attending private schools as well. During the 2015-2016 school year, there were approximately 123,000 Emirati students compared to 588,000 non-
Emirati students enrolled in the private school sector, accounting for approximately $17 \%$ of all private school students in the UAE (see Figure 3). For instance, this trend towards increasing private education enrollment of Emiratis can be seen in Dubai, where there has been a steady increase since at least the late 1990s. While in the academic year 1998-1999 approximately 29\% of all Emirati students attended private schools in Dubai, this level rose to $54 \%$ in 2006-2007, and further increased to $57 \%$ in 2018-2019 to its highest level so far (Dubai Statistics Center, 2007, 2019).

Figure 3: Student Nationalities in Public and Private Schools Across the UAE (2015-16)

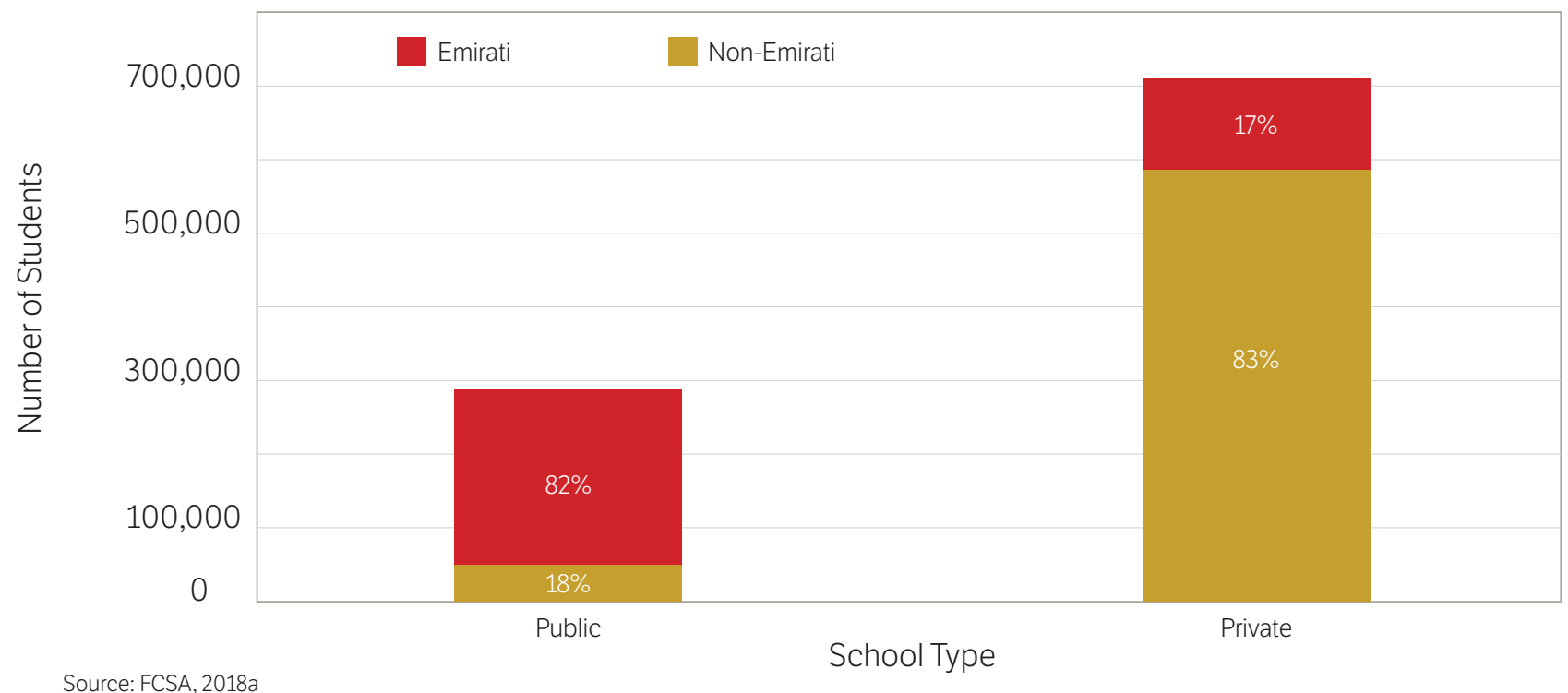




\section{Initiatives for Students with Special Needs}

In 2008, the National Project for Inclusion of People with Special Needs was introduced. The program highlights the importance of providing facilities, educational opportunities, and socially integrating people with special needs in the public and private school systems. In 2009, the Ministry began integrating students from special needs centers into regular public schools to complement the work of government and private organizations in offer training, education, and care (UAE Government, 2020d). These students are assessed according to individual educational plans, and are automatically promoted to the next grade at the end of each academic year. In 2016, H.H. Sheikh Mohammed bin Rashid Al Maktoum introduced the term People of Determination to describe people who were formally referred to as individuals with special needs (Zayed University, 2020).

The regulatory frameworks, curricula, and sources of funding differ between the UAE's public and private education sectors. For this reason, the following sections describe each sector separately. In general, public schools are regulated and operated by the MOE across the seven emirates. Schools operated by private education providers are regulated by special regulatory bodies in each emirate that, in turn, follow the laws and regulations set by the $\mathrm{MOE}$.

\section{Public Schools in the UAE}

The currently 619 public schools in the UAE are mixedgender at the primary, and single-sex at the secondary level, with Arabic as the primary language of instruction. They are divided into a four-tier system covering 14 years of education: kindergarten (KG1 - KG2), primary or elementary level (Grades 1-4, also known as Cycle 1), intermediate level (Grades 5-8, known as Cycle 2), and secondary level (Grades 9-12, known as Cycle 3) (UAE Government, 2020e).

In 2018, the MOE announced a gradual integration of genders in elementary school classes starting with Grade 1 , scheduled to eventually include Grades 1 through to 4 (UAE Government, 2020f). With schools largely given autonomy over the directive's implementation, media reports have cited parents' concerns over integration. Proponents nonetheless suggest that the presence of girls in classrooms will have a positive impact on boys' behaviour (Rizvi \& Dajani, 2018). Additionally, public boys' schools have seen an increasing number of female teachers, as well as leadership roles in administration, such as principals, and social workers.

\section{Regulatory Framework}

Public schools in the UAE are regulated and operated by the MOE. This encompasses aspects such as the curriculum, strategic planning, school operations, but also the dates of the academic year and so forth. On the emirate level, MOE-affiliated agencies operate public schools, which are commonly called 'Education Zones' such as Dubai Education Zone, Sharjah Education Zone, or Ras Al Khaimah Education Zone. In the past, these Education Zones were responsible for the supervision and implementation of federal and local policies, and for supporting administrative staff. However, as of 2020, Education Zones are primarily tasked with conducting school inspections at private and public schools in the emirate, while most coordination and support of administrative staff and teachers in the Northern Emirates, such as Ras Al Khaimah, has shifted to the Ministry of Education in Dubai (personal communication with Ras Al Khaimah Education Zone official, 2020).

Other noteworthy developments in the regulation of the public school sector relate to Sharjah and Abu Dhabi. In the Emirate of Sharjah, the Sharjah Education Council (SEC) was established in 2006 and restructured in 2018 to now oversee nurseries and daycare centers under the leadership of the MOE, while the Ministry regulates and operates public schools through the Sharjah Education Zone. In Abu Dhabi, the Department of Education and Knowledge (ADEK) was tasked with the oversight of both public and private schools until the end of 2017. However, this changed in November 2017 when the operation and management of public schools was returned to the Ministry of Education with this transition still being ongoing. An overview of the regulatory bodies for private and public education can be referenced in Appendix D.

\section{Students and Teachers}

Across all regions, Emirati students make up the majority of public school students. In this context, Figure 4 below shows the breakdown of the number of Emirati versus expatriate students in UAE public schools by region.

During the 2015-16 school year, there were 11,167 Emirati and 16,180 expatriate teachers in public schools in the UAE. Overall, the proportion of Emirati and expatriate teachers varies between individual emirates: while in the emirates of Sharjah and Ajman expatriates and nationals both account for approximately half of all public school teachers, in Ras Al Khaimah, Fujairah, and Dubai, female 
Figure 4: Student Nationalities in Public Education Across the UAE, by Region (2015-16) ${ }^{3}$

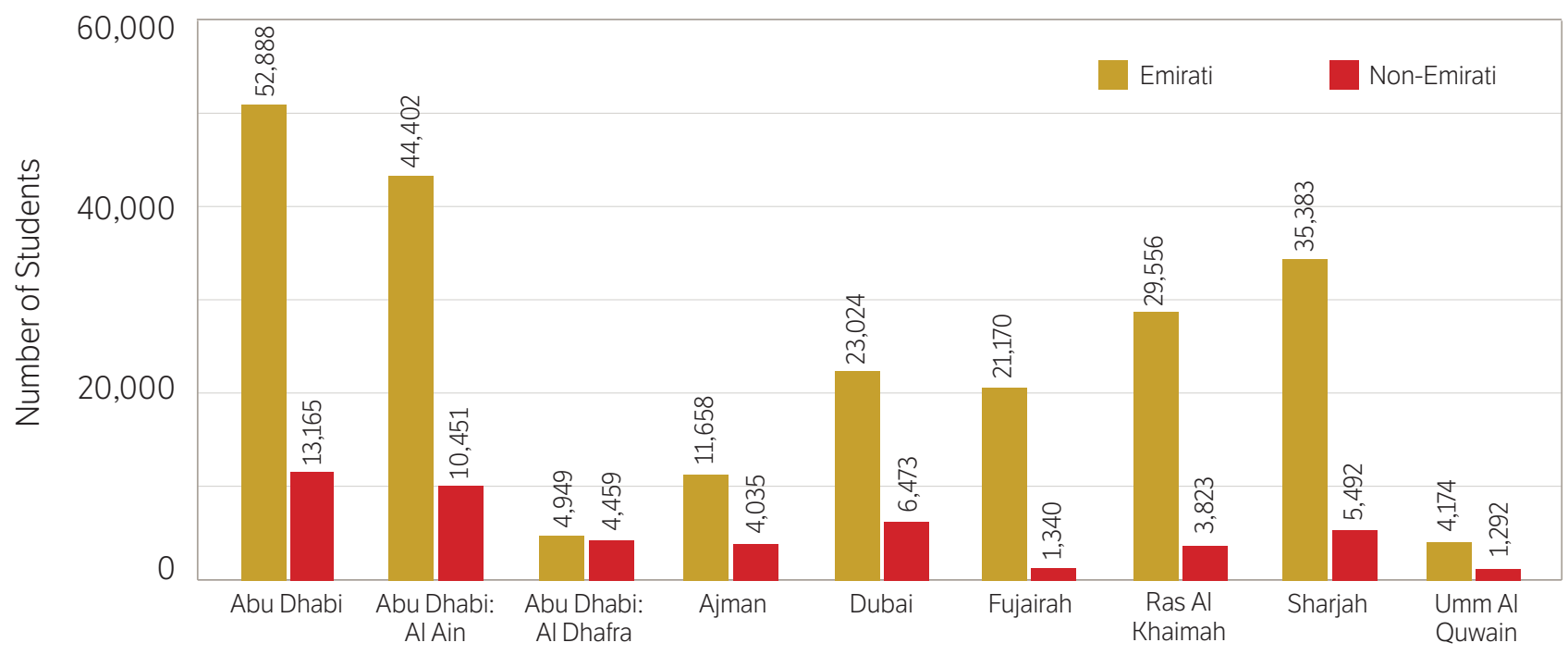

Source: MOE, 2016

Emirate

Emirati teachers make up the largest proportion of teachers. Figure 5 also demonstrates that in Abu Dhabi female expatriate teachers make up the majority $(6,113)$, followed by male expatriate teachers $(3,114)$. Similarly, in Al Ain, male and female expatriates combined make up 2,798 teachers, compared to 2,027 female Emirati teachers. While most of the non-national teachers are
Arab male expatriates ${ }^{4}$ who teach at boys' intermediate and secondary schools (Ridge, 2014), ${ }^{5}$ there is a lack of male Emirati teachers. In 2017, there were 249 male Emirati teachers in Abu Dhabi, compared to 1,918 Emirati female teachers. The lowest numbers of male Emirati teachers were recorded in Ajman and Umm Al Quwain with 15 and zero, respectively.

Figure 5: Nationalities of Public School Teachers in the UAE, by Region (2015-17)

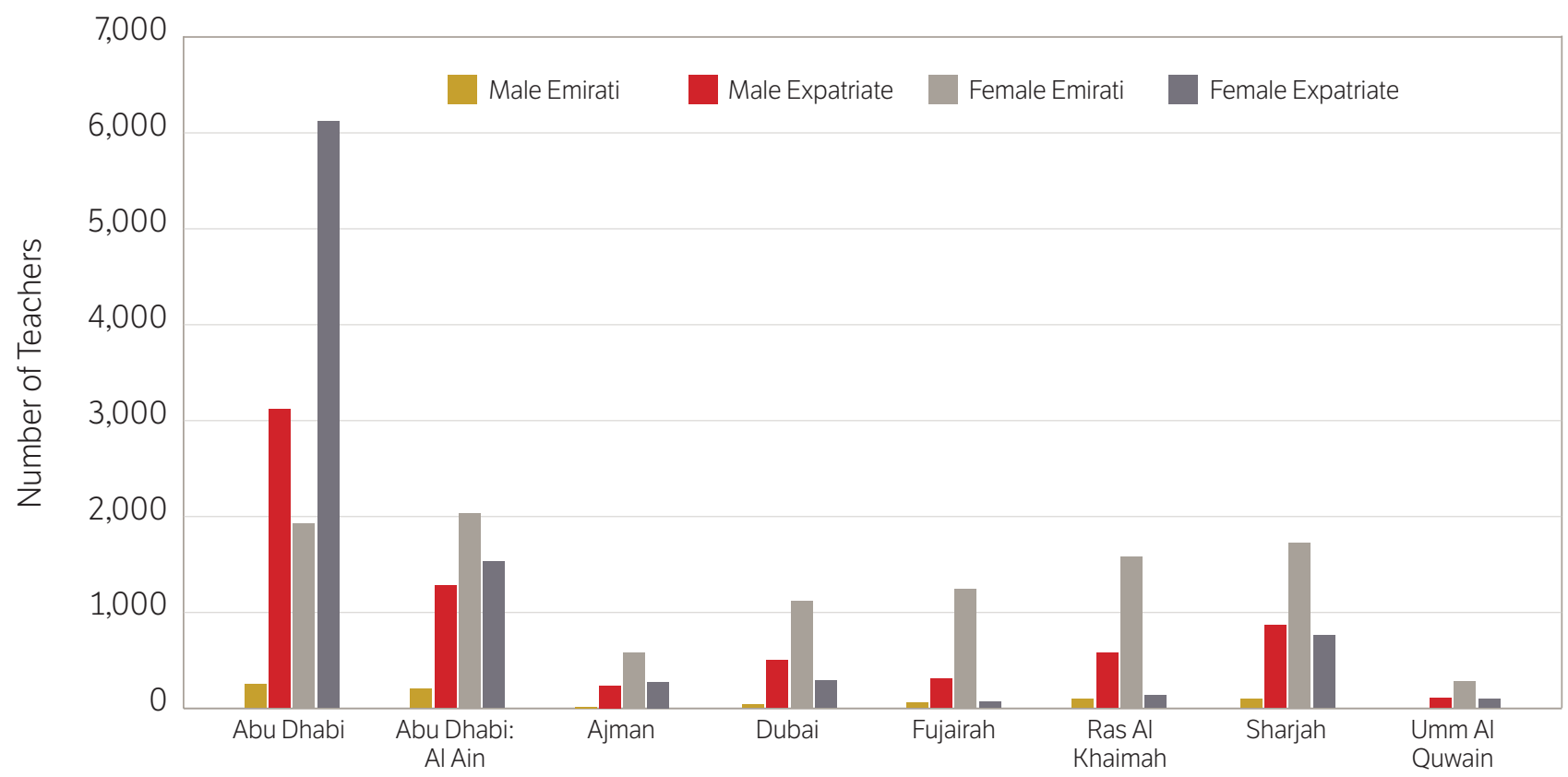

Emirate

Source: FCSA 2018b, 2019b

\footnotetext{
3 In the 2016/2017 academic year, the Ministry of Education begun reporting student numbers by gender, without reference to nationality. These numbers represent the most recent information on student nationalities.

${ }_{4}^{4}$ To learn more about the case of Arab expatriate teachers see Expatriate Teachers and Education Quality in the Gulf Cooperation Council (Ridge, Shami, Kippels \& Farah, 2014)

5 Table 4 on page 16 of the Fact Sheet shows teachers by cycle, nationality, and gender in the emirate of Ras Al Khaimah.
} 
As part of the UAE's current national strategy for development, Vision 2021, the government aims to increase the number of Emiratis in the job market and their contribution to the economy, also known as Emiratization or Tawteen in Arabic. In this context, the fluctuating share of nationals in the overall population of public school teachers demonstrates an area of potential growth and underscores the need for emirate-specific approaches to building up the capacities of nationals.

\section{Curriculum}

The Ministry of Education is responsible for implementing the national curriculum at public schools, including the production of subject syllabi and the preparation and oversight of assessments across the country (see Box 3 for additional information about international assessments and standardized testing in the UAE).

Since the UAE was founded, there have been several reforms ${ }^{6}$ that have altered the public school curriculum. For example, the Madares Al Ghad (Schools of Tomorrow) program was started in select public schools in 2007, using a new curriculum that emphasized the use of electronic resources, student-centered approaches to learning, and the use of English as the language of instruction for mathematics and science. While the progam was discontinued in 2015 (Jonny, 2015), mathematics and science instruction in English has been integrated into the national curriculum (UAE Government, 2020g).

More recently, in 2016, the government introduced new subjects, such as innovative design, health sciences, career guidance, life skills, and business management, to the curriculum in primary and secondary public schools to expand the breadth of educational offerings (UAE Government, 2020h).

\section{Stages and Streams of Education}

Throughout Cycles 2 and 3 of public school, specific streams offer more differentiation based on students' academic performance and inclination. Starting in Grade 6 through to Grade 12, the Elite stream caters to academically outstanding students, with a focus on mathematics and science (MOE, 2020b). Students apply to join the Elite stream and can test into it through the standardized, computer-based Advantage Emirates Standardized Test (EmSAT), administered in Grades 4, 6, 8 , and 10.
After completing Grade 8, students may additionally choose between remaining in a General stream or joining an applied stream. For students interested in applied learning and practical skills, this stream offers a curriculum that involves vocational skills, competencybased assessments, a focus on a specific sector (such as engineering, business administration, or health and social care) and two weeks of work placements in Grades 11 and 12 (MOE, 2020c). After finishing Grade 9, students in the General stream can choose either to remain in the General stream or to join the Advanced stream, also depending on their academic performance. Both General and Advanced stream students will continue Grades 10 through to 12 .

\section{Financing}

Public schools in the UAE are funded by the federal government. The federal government funds the building of schools, teachers' salaries, textbooks, the transportation of students, and, in theory, all other capital and recurrent expenditures on education. From kindergarten through to secondary school, Emirati citizens can attend government schools, colleges, and universities free of charge until the completion of undergraduate education (UAE Government, 2020i).

The share of the UAE government's budget allocated to education has ranked relatively highly when compared to the world average expenditure on education, which fluctuated between $13.5 \%$ and $14.7 \%$ from 2000 to 2012 (World Bank, 2016). In its most recent budget for the 2020 fiscal year, the UAE government reports spending AED 10,41 billion on public, higher, and university education programs, which represents $14.8 \%$ of its AED 61.35 billion total budget (USD 16.7 billion) (Ministry of Finance, 2020).

\footnotetext{
${ }^{6}$ For more detailed information about the UAE public school curriculum, see Curriculum Development in the United Arab Emirates (Ridge, Kippels, \& Farah, 2017).
} 


\section{Participation in International Assessments and Standardized Testing ${ }^{7}$}

The UAE participates in international assessments such as the Programme for International Student Assessment (PISA), the Trends in International Mathematics and Science Study (TIMSS), the Progress in International Reading Literacy Study (PIRLS), and the Teaching and Learning International Survey (TALIS). In addition, the UAE also introduced the Emirates Standardized Test (EmSAT) in 2017, a series of computer-based tests, which measures students' skills in Arabic, English, Maths and Science. This national system of standardized testing is mandatory in public schools with three levels of testing: Baseline Test (Grade 1), Advantage Test (Grade 4, 6, 8, 10), and Achieve Test (Grade 12). These tests replaced the previous Common Educational Proficiency Assessment (CEPA) as a national higher education entry requirement (EmSAT, 2020). Table A shows when the emirates of Dubai and Abu Dhabi, but also the UAE as a whole, have started to participate in international assessments and standardized tests, in addition to their mean scores.

Table A: UAE’s Participation in International Assessment and Standardized Testing

\begin{tabular}{|l|c|c|c|c|c|c|c|}
\hline PISA Assessment Year & 2000 & 2003 & 2006 & 2009 & 2012 & 2015 & 2018 \\
\hline UAE Participation & - & - & - & $\begin{array}{c}459 \\
\text { (Dubai only) }\end{array}$ & 441 & 432 & 433 \\
\hline TIMSS & 1995 & 2003 & 2007 & 2011 & 2015 & 2019 \\
\hline UAE Participation & - & - & 444 & 434 & 452 & $\begin{array}{c}\text { (TBA in } \\
\text { December } \\
\text { (Dubai only) }\end{array}$ \\
\hline PIRLS & 2001 & 2006 & 2011 & 2016 & & \\
\hline UAE Participation & - & - & 439 & 450 & & \\
\hline TALIS & 2008 & 2013 & 2018 & & & \\
\hline UAE Participation & - & (Abu Dhabi & Xnly) & X & & & \\
\hline
\end{tabular}

The UAE's participation in international assessments allows for cross-national and longitudinal comparisons of academic achievement in the country. In addition to collecting data on core subject achievement (e.g., in mathematics, science, and reading), international assessments also include supplementary survey data that provide insight into additional areas such as parental involvement, student resources, teachers, types of schools, and student learning styles. Academics and policymakers are able to use this information to identify strengths and challenges to better support education in the country.

Launched in 2000 by the Organisation for Economic Co-operation and Development (OECD), the Programme for International Student Assessment (PISA) is administered every three years and measures achievement levels of 15-year-old students in mathematics, reading, and science. Trends in International Mathematics and Science Study (TIMSS) was first conducted in 1995 by the International Association for the Evaluation of Educational Achievement (IEA) and is administered every four years to measure the mathematics and science skills of Grade 4 and Grade 8 students. PIRLS was started in 2001 by the IEA to measuring the reading proficiency of Grade 4 students, and is conducted every five years. The OECD's Teaching and Learning International Survey (TALIS), a self-reporting survey for teachers and principals, was first conducted in 2008 and takes place every five years. 


\section{Private Schools in the UAE}

Mainly reflecting the needs of the UAE's large expatriate population, the private school sector has grown significantly and provides a wide range of curriculum offerings with various languages of instruction.

\section{Regulatory Frameworks and Structures}

Private schools in the UAE that primarily cater to the country's expat population are generally regulated by different entities across the seven emirates while following the laws and regulations set by the MOE. In 2006, Dubai established its Knowledge and Human Development Authority (KHDA), to regulate the growing private education sector, and since then, two other emirates have started to create comparable entities.

In Abu Dhabi, there is the Abu Dhabi Department of Education and Knowledge (ADEK), which was founded in 2005 as the Abu Dhabi Education Council (ADEC), responsible for managing, and implementing various educational development strategies and initiatives in the emirate. Starting in 2018, ADEC was restructured into $A D E K$, and its mandate was focused on the licensing, regulation and inspection of private schools in $\mathrm{Abu}$ Dhabi, including fees, and investments (ADEK 2020b). Additionally, in the emirate of Sharjah, the Sharjah Private Education Authority (SPEA) was established in 2018 to both evaluate and regulate private sector schools and universities in the emirate. SPEA operates under the supervision of the Executive Council of the emirate and is tasked with raising the quality of private education and attracting investment in the sector (SPEA, 2020). In the remaining emirates, the MOE more directly regulates private schools through its Education Zones, while private operators may also coordinate with additional federal entities for the allocation of land, real estate, and other aspects.

Each of the emirate-level regulatory bodies has their own private school licensing requirements, ranking systems, inspection, and tuition fee criteria. The multitude of organizations across the country contributes to a complex combination of regulatory bodies for private schools, which sometimes even results in competition for resources and control between federal and emiratelevel authorities (Nolan, 2012).

While private schools follow their own national or international curriculum, four subjects are mandatory following MOE regulations: Islamic education, Arabic language instruction, UAE social studies, and UAE moral education (KHDA, 2019a). In private schools' Grades 1 through to 9, students of all nationalities receive Arabic language instruction, and participate in 1 weekly lesson of UAE social studies. For Arab and non-Arab Muslim students, Islamic Studies classes are provided from Grade 1 through to 12 (Ridge et al., 2015).

\section{Students and Teachers}

The UAE's private education sector has grown rapidly in response to the needs of the expatriate population. According to MOE figures, the private sector now caters to approximately $74 \%$ of the country's student population, including both Emirati and expatriate students (see Figure 6), in 643 schools (MOE, 2018). In Dubai, that percentage is even higher, with $90 \%$ of all students in the emirate educated in private schools during the 2018-19 academic year (Dubai Statistics Center, 2019).

Figure 6: Student Nationalities in Private Education Across the UAE, by Region (2015-16) ${ }^{8}$

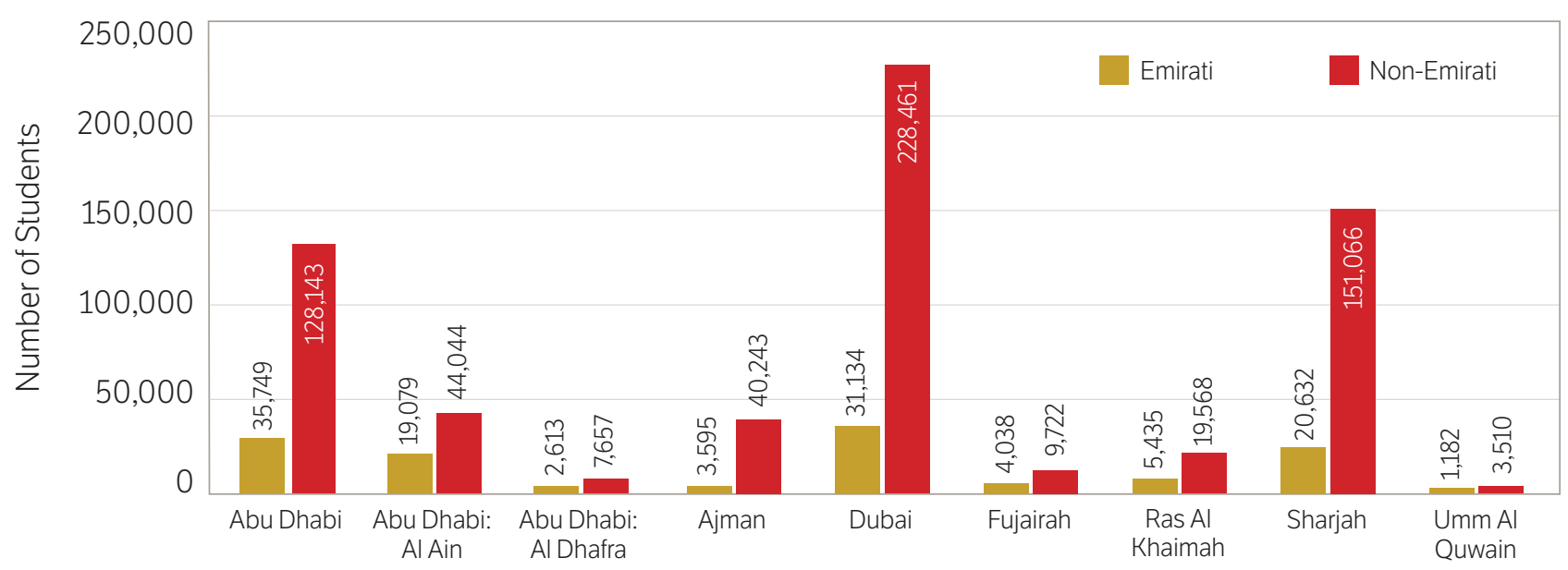

Source: MOE, 2016

Emirate

\footnotetext{
8 Starting in the 2016/2017 academic year, the Ministry of Education has begun reporting student numbers by gender, without reference to nationality. These numbers represent the most recent information on student nationalities.
} 


\section{Curriculum}

Private schools in the UAE offer a wide range of curricula. In the 2018-19 academic year, in Dubai alone there were 15 curriculum options offered in its network of private schools. In Dubai, the largest number of private schools offer curricula from the United Kingdom (UK) (80 schools), the United States (42 schools), and India (37 schools) (KHDA, 2019b). In Abu Dhabi, there are 14 different types of curricula available, and the United States and UK curricula are also amongst the most popular there (Abu Dhabi Government, 2020). Additional curricula offered at private schools in the UAE, amongst others, include those from France, the Philippines, Germany, and Pakistan.

\section{Financing}

In the UAE, the majority of private schools are operated by for-profit providers, with international companies such as GEMS, SABIS, and Taaleem holding a large share of the market. Driven by investors' expectation of for-profit schools to generate profit, school fees are a popular point of contention between school operators, regulators, and stakeholders like parents and teachers. In a worldwide comparison, parents in the UAE spend around 100,000 USD on their children's education from primary school to undergraduate level, which is the second highest number in the world after Hong Kong (Gray, 2017).

Non-profit schools currently comprise less than $25 \%$ of all private schools. However, these schools have been found to hire more qualified teachers and provide better benefits to their stakeholders, which include teachers and students' families alike (Ridge et al., 2016).

One study in the UAE found that a greater percentage of teachers in non-profit schools held official teaching certificates or licenses when compared to teachers in forprofit schools (94\% versus 85\%) (Ridge et al., 2016). The same study also found that teachers at non-profit schools had salaries 1.5 to 2 times higher than for-profit school teachers, while also receiving better benefits and having a smaller number of students per class. In addition to the better conditions reported by teachers, parents also saw benefits to having their children enrolled in non-profit schools. Parents said they were happier about the valuefor-money of their child's education than those parents who had a child in a for-profit institution (Ridge et al., 2016).

\section{Higher Education in the UAE}

Higher education in the UAE consists of public, semi-public, and privately operated institutions. The institutions across each of these sectors offer various degrees at the associate's, bachelor's, master's, and doctorate levels. Higher education is under the auspices of the Ministry of Education, which is responsible for setting policies and accrediting universities through the Commission for Academic Accreditation (CAA). In line with new licensing and accreditation standards published in 2019, the Ministry of Education guidelines apply to all tertiary education institutions across the

Figure 7: Number of Graduates from Tertiary Education by Gender

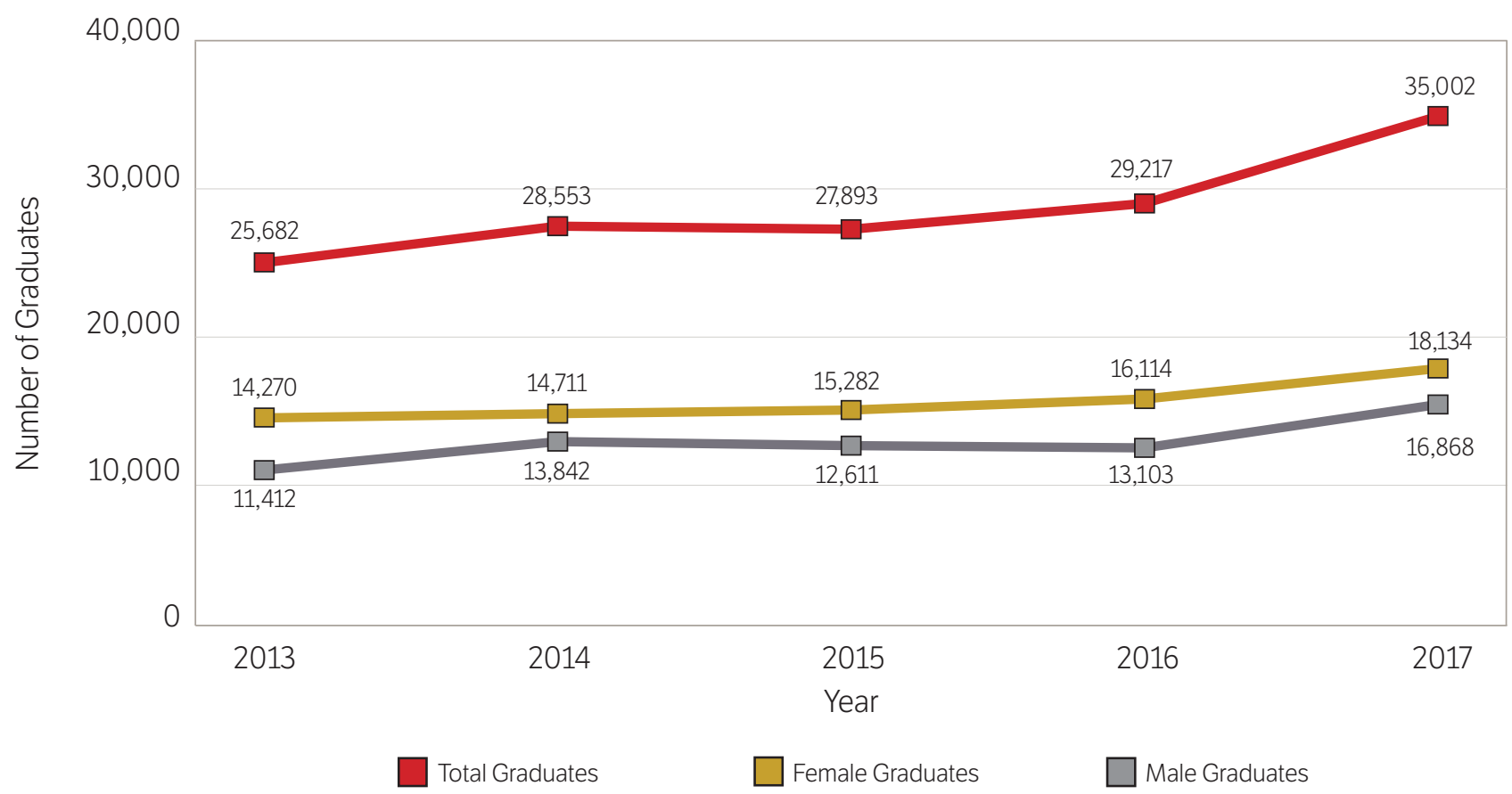


emirates, including government universities (federal and local), private universities, specialized universities (e.g. police and army), as well as branches of international universities, including those in the country's free zones. Universities are assessed across 11 academic and administrative aspects, including finance, research activities and governance (MOE, 2019).

In addition to accreditation through the CAA and licensing from the MOE, emirate-level authorities, such as the Ras Al Khaimah and Dubai Free Zones (geographical areas specifically designated for international collaborations), are responsible for granting universities commercial licenses to operate (Rensimer, 2015).

There has been a rapid increase in the number of accredited higher education institutions over the last 20 years, growing from 5 in 1990 to 77 in 2020 (CAA, 2020). This growth has primarily been in the private sector. However, the exact number of higher education institutions in the UAE is frequently changing as new institutions open, others close, and some merge (Center for Higher Education Data and Statistics [CHEDS], 2012). In 2012, a report by the Center for Higher Education Data and Statistics (CHEDS) found that there were 102 active higher education institutions in the UAE, with only 69 of them being accredited by the CAA (CHEDS, 2012). In 2020, the CAA accredited 77 of the UAE's active higher education institutions (CAA, 2020).

While the number of graduates has been increasing in recent years (Figure 7), enrollment in higher education in the UAE was estimated at around 191,794 students in 2017 (Figure 8). In this context, business was the specialization with the highest enrollment for both undergraduate and graduate studies in 2017 (KHDA 2017; PricewaterhouseCoopers, 2018).

Figure 8: Enrollment in Higher Education (2016-17)

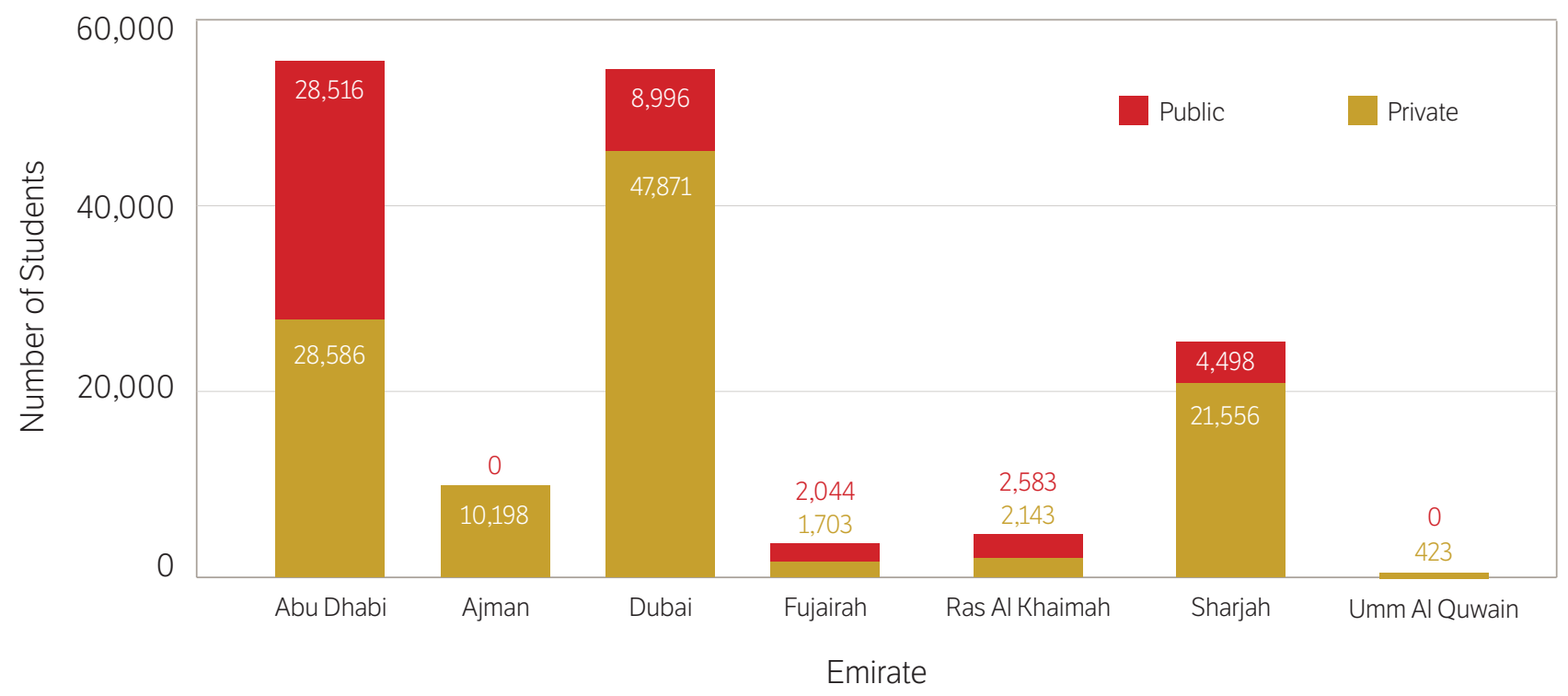

Source: FCSA, 2018c 
The number of international degree-seeking students in the UAE rose from 48,653 in 2011 to 77,463 in 2016. As a result, private higher education institutions in the UAE feature highly diverse international student bodies, such as the the American University of Sharjah (AUS) that was reported to have the largest percentage of foreign students worldwide at 84\% (Kamal \& Trines, 2018). The increase in international student enrollment and the top origin countries of international students can be seen in Figures 9 and 10 respectively.

Figure 9: Number of Inbound Degree-Seeking Students in the UAE

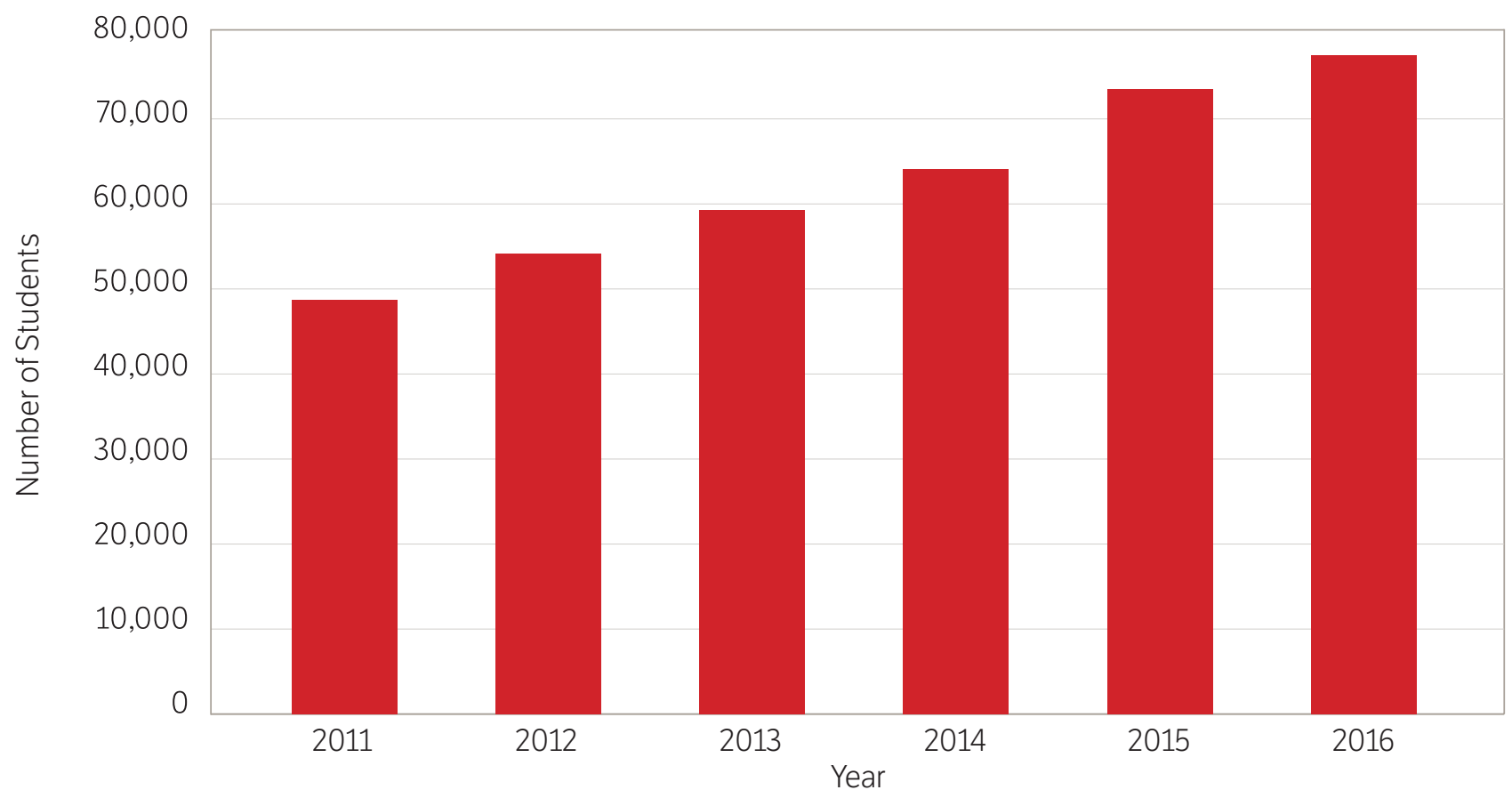

Source: UNESCO Institute of Statistics (UIS), 2020b

Figure 10: International Students in Tertiary Education in the UAE by Region of Origin (1971)

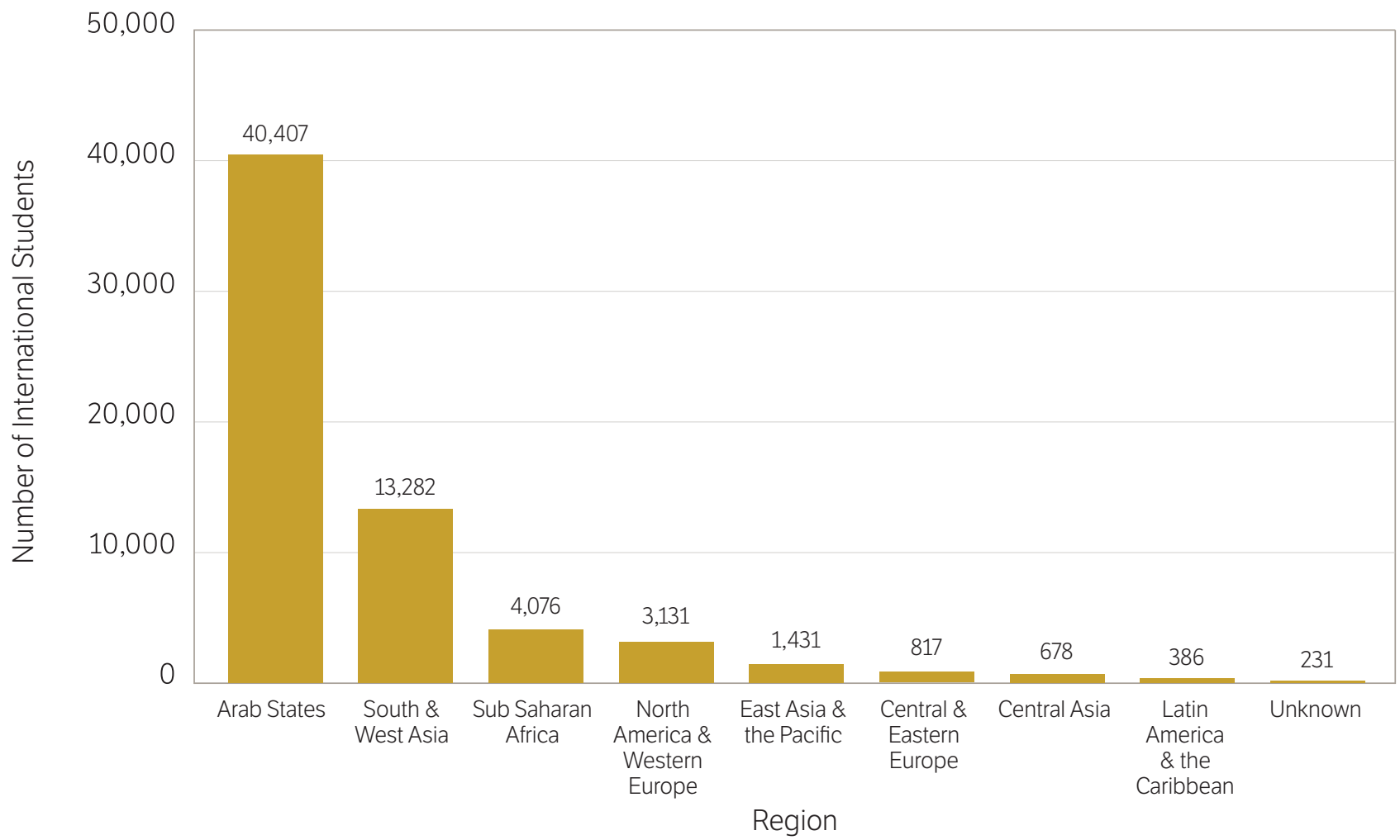


In addition to growth in degree-seeking international students in the UAE, the UAE is also a sending country for students pursuing higher education degrees. In 2016, 7.1\% of Emirati nationals pursued tertiary degrees internationally with the UK and the US as the primary destinations (Kamal \& Trines, 2018).

\section{Public Universities}

Public universities are open to Emirati students at the undergraduate level while some, such as UAE University, also enroll expatriate students (Swan, 2016; UAE University, 2016a). The three federal public higher education institutions in the UAE are noted in Table 3. At these institutions, the official language of instruction is English, while Emirati students can enroll free of charge until the completion of their undergraduate education.

In addition to federal universities, there are also other public, emirate-level, higher education institutions. The Khalifa University of Science \& Technology (KU) is one such example in Abu Dhabi, which was created through a merger of the previous Khalifa University, Masdar Institute, and the Petroleum Institute in February 2017, reportedly in an effort to combine resources and strengthen institutional achievements (Khalifa University, 2020).

Table 3: Federal UAE Higher Education Institutions

\begin{tabular}{|c|c|c|c|}
\hline Name & $\begin{array}{c}\text { Year } \\
\text { Established }\end{array}$ & $\begin{array}{c}\text { Number of } \\
\text { students }\end{array}$ & About \\
\hline $\begin{array}{l}\text { UAE } \\
\text { University }\end{array}$ & 1976 & $\begin{array}{l}15,019 \\
(2018 / 2019)\end{array}$ & $\begin{array}{l}\text { UAE University is the country's oldest higher education } \\
\text { institution. Located in AI Ain (in the emirate of Abu Dhabi), it } \\
\text { consists of nine colleges. In 2009, UAE University was the first } \\
\text { federal university in the UAE to institutionalize a Ph.D. program. }\end{array}$ \\
\hline $\begin{array}{l}\text { Higher } \\
\text { Colleges of } \\
\text { Technology } \\
\text { (HCT) }\end{array}$ & 1988 & $\begin{array}{l}20,990 \\
(2019 / 2020)\end{array}$ & $\begin{array}{l}\text { HCT's } 17 \text { campuses are spread across the country, making } \\
\text { it especially popular among female students who often live } \\
\text { at home while undertaking their studies. HCT offers applied } \\
\text { diplomas, bachelor's degrees, and master's programs. }\end{array}$ \\
\hline $\begin{array}{l}\text { Zayed } \\
\text { University } \\
\text { (ZU) }\end{array}$ & 1998 & $\begin{array}{l}10,648 \\
(2018 / 2019)\end{array}$ & $\begin{array}{l}\text { ZU has two campuses in Dubai and Abu Dhabi that offer both } \\
\text { undergraduate and graduate degrees (Zayed University, } \\
\text { 2016a). Originally open only to women, the university opened } \\
\text { admissions to men in } 2009 \text { (Zayed University, 2016b). }\end{array}$ \\
\hline
\end{tabular}

Sources: HCT, 2020; UAE University, 2020; Zayed University, 2020

\section{Semi-Public Universities}

The second type ofuniversities in theUAE are semi-public institutions. Owned by private and/or state shareholders, these universities operate within specific emirates with primarily expatriate student populations. Semi-public universities may receive partial or full financial backing from the federal or local emirate governments. Such financial arrangements vary considerably, as do levels of government involvement and oversight. Institutions in this category include Abu Dhabi University, New York University Abu Dhabi (NYUAD), Sorbonne University Abu Dhabi, the American University of Dubai (AUD), the American University of Sharjah (AUS) and the American University of Ras Al Khaimah (AURAK).

\section{Private Universities}

The UAE private sector encompasses a broad range of higher education institutions, including international branch campuses as well as independent institutes, many of which operate in free trade zones. While private universities primarily serveexpatriates, several institutions have relatively high percentages of Emirati students in relation to their total enrollments (Swan, 2014). Some of the more well-known private universities include: The University of Wollongong in Dubai; University of Bolton in Ras Al Khaimah; Middlesex University Dubai, or also London Business School in Dubai. 


\section{K-12 Education in Ras Al Khaimah}

As in other emirates, Ras Al Khaimah has a mix of public and private schools. However, compared to other emirates, public schools are more common in Ras Al Khaimah. Excluding vocational and adult education, Ras Al Khaimah is home to 58 government and 33 private schools, as well as 14 public kindergartens and
39 licensed private private early-childhood education centers. (MOE, 2020d). While some public schools offer all three cycles of the MOE curriculum at one school, there are several standalone schools offering only one or a combination of cycles. For a more detailed overview of the number and type of schools, as well as the number of students by cycle, see Figure 11 .

Figure 11: Distribution of Students and Schools in Ras Al Khaimah by Cycle (2018-2019)
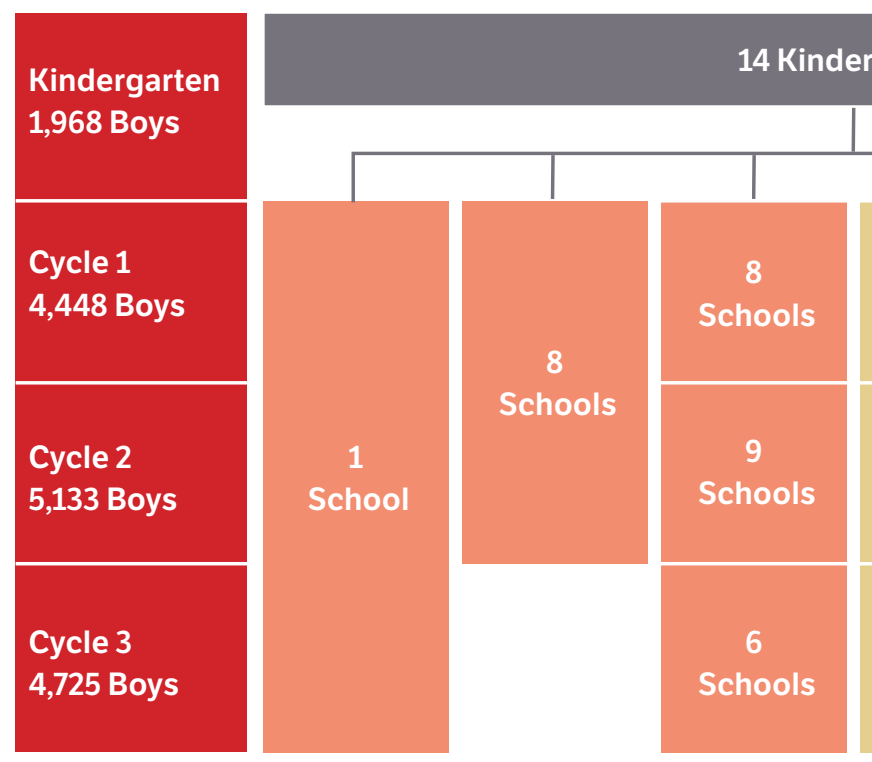

\section{garten}
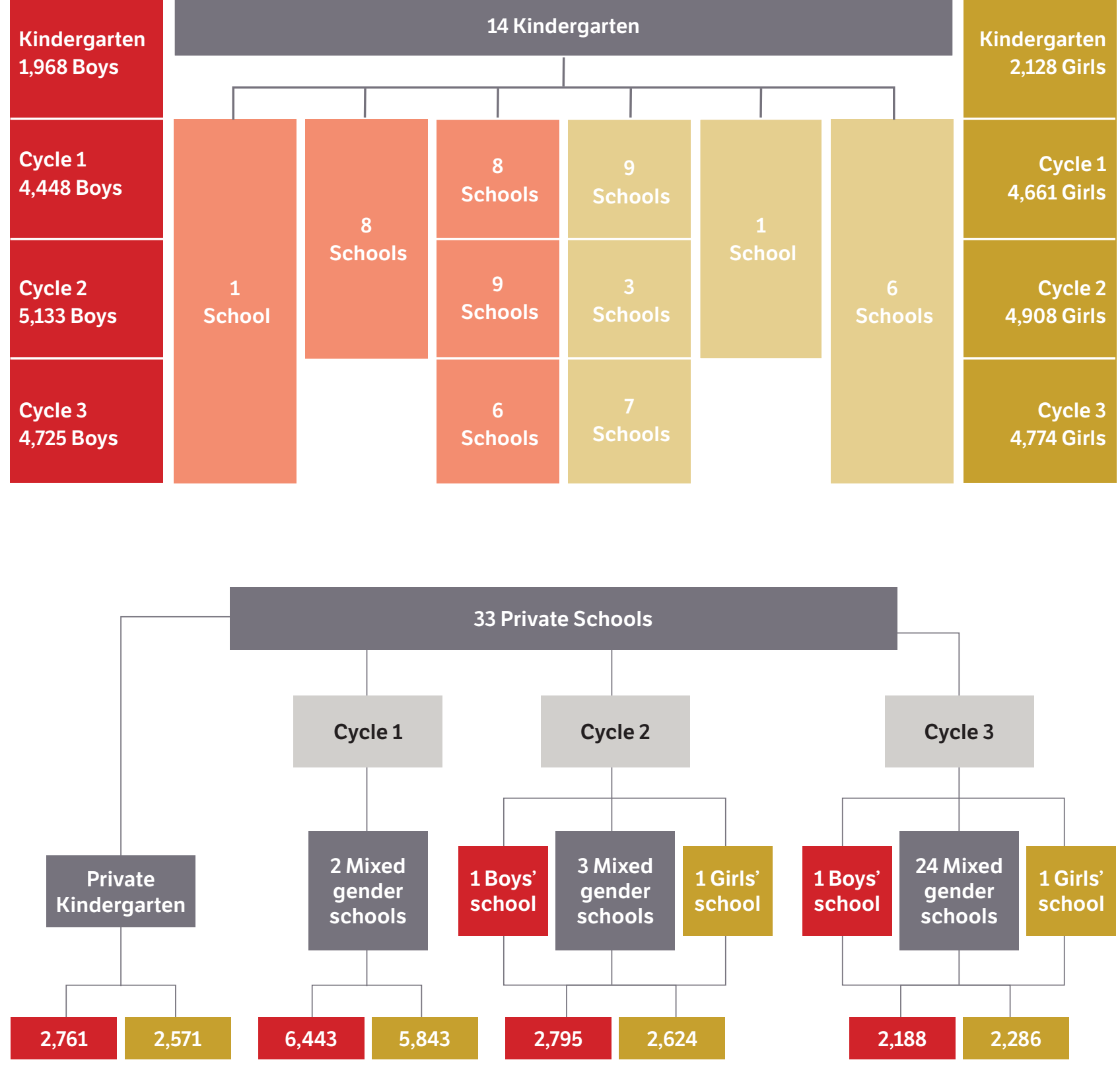

Source: MOE, 2018 
The most recent publicly available data on student nationalities in Ras Al Khaimah shows that in the academic year of 2015/2016, the majority of Emirati children in Ras Al Khaimah attended public schools, accounting for $54 \%$ of total enrollment, and $89 \%$ of total public school enrollment in the emirate (see Table 4). During the same year, $22 \%$ of the students enrolled in the emirate's private schools were Emirati.

Table 4: Students in Public Schools of Ras Al Khaimah by Cycle and Nationality (2015-16)

\begin{tabular}{|c|c|c|c|}
\hline Stage & Nationality & $\begin{array}{l}\text { Number of } \\
\text { Students }\end{array}$ & Percentage \\
\hline \multirow{3}{*}{ Kindergarten } & Emirati & 3,702 & $98 \%$ \\
\hline & Expatriate & 90 & $2 \%$ \\
\hline & Total & \multicolumn{2}{|c|}{3,792} \\
\hline \multirow{3}{*}{$\begin{array}{l}\text { Cycle } 1 \\
\text { (Primary) }\end{array}$} & Emirati & 11,325 & $91 \%$ \\
\hline & Expatriate & 1,096 & $9 \%$ \\
\hline & Total & \multicolumn{2}{|c|}{12,421} \\
\hline \multirow{3}{*}{$\begin{array}{l}\text { Cycle } 2 \\
\text { (Preparatory) }\end{array}$} & Emirati & 8,991 & $87 \%$ \\
\hline & Expatriate & 1,342 & $13 \%$ \\
\hline & Total & \multicolumn{2}{|c|}{10,333} \\
\hline \multirow{3}{*}{$\begin{array}{l}\text { Cycle } 3 \\
\text { (Secondary) }\end{array}$} & Emirati & 5,538 & $81 \%$ \\
\hline & Expatriate & 1,295 & $19 \%$ \\
\hline & Total & \multicolumn{2}{|c|}{6,833} \\
\hline Grand total & & \multicolumn{2}{|c|}{33,379} \\
\hline
\end{tabular}

Source: MOE, 2016
In the 2016/2017 academic year, there were 1,663 Emirati teachers (70\%) and 707 expatriate teachers (30\%) in the Ras Al Khaimah public school teacher workforce. As shown in Table 5, the majority of expatriate teachers work in Cycle 2 and Cycle 3 boys' schools, which is similar to other emirates. The majority of these expatriate teachers have been working in the UAE for over 10 years (Ridge et al., Forthcoming).

Table 5: Teachers in Public Schools in Ras Al Khaimah by Cycle, Nationality, and Gender (2016-17)

\begin{tabular}{|c|c|c|c|c|}
\hline $\begin{array}{l}\text { Educational } \\
\text { Stage }\end{array}$ & Nationality & Male & Female & Percentage \\
\hline \multirow{3}{*}{ Kindergarten } & Emirati & 0 & 138 & $64 \%$ \\
\hline & Expatriate & 1 & 76 & $36 \%$ \\
\hline & Total & 1 & 214 & \\
\hline \multirow{3}{*}{$\begin{array}{l}\text { Cycle } 1 \\
\text { (Primary) }\end{array}$} & Emirati & 5 & 789 & $88 \%$ \\
\hline & Expatriate & 17 & 92 & $12 \%$ \\
\hline & Total & 22 & 881 & \\
\hline \multirow{3}{*}{$\begin{array}{l}\text { Cycles } 2 \text { \& } 3 \\
\text { (Preparatory } \\
\text { \& } \\
\text { Secondary) }\end{array}$} & Emirati & 83 & 648 & $51 \%$ \\
\hline & Expatriate & 557 & 153 & $49 \%$ \\
\hline & Total & 640 & 801 & \\
\hline Grand Total & & 1,896 & 2,559 & \\
\hline \multicolumn{2}{|c|}{$\begin{array}{l}\text { Percent of Grand Total } \\
\text { (by Gender) }\end{array}$} & $43 \%$ & $57 \%$ & \\
\hline
\end{tabular}

Source: FCSA 2018b, 2019b
As in the wider UAE, private schools in Ras Al Khaimah offer a large variety of curricula, with eight different types available (Ras Al Khaimah Education Zone, 2020). The curricula options at 33 private schools are shown in Figure 12, with the most common being the MOE curriculum (17 schools), followed by an Indian curricula ${ }^{9}$ (6 schools), the United Kingdom (4 schools), and the United States ${ }^{10}$ (3 schools).

Figure 12: Curricula Followed by Private Schools in Ras Al Khaimah (2019-2020)11

\section{Private School Curricula in Ras Al Khaimah}

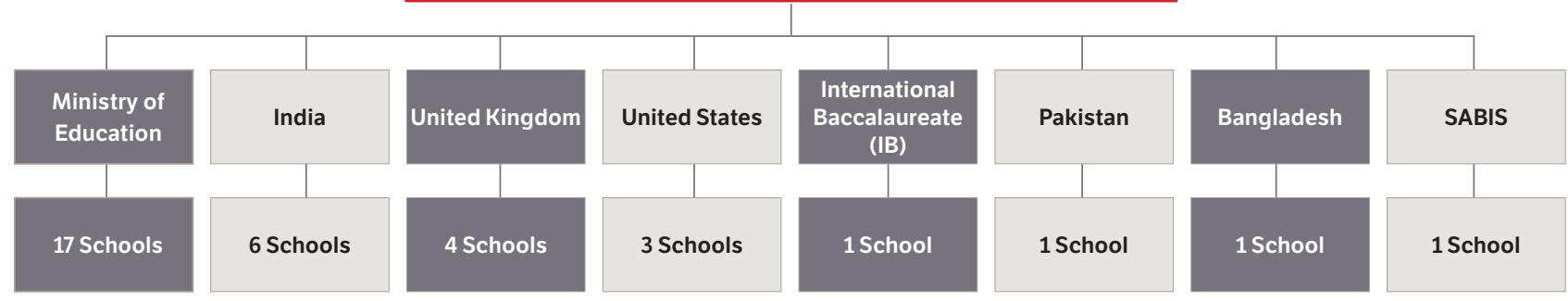

Sources: Ras Al Khaimah Education Zone, 2020a

\footnotetext{
9 These include the Central Board of Secondary Education (CBSE) system and the Indian School Certificate Examinations (ISCE) syllabus.

${ }_{10}$ Two of the American curriculum schools in Ras Al Khaimah list the Common Core State Standards, while one of the American schools in Ras Al Khaimah specifies the Pennsylvania State Academic Standards and Benchmarks in addition to the Common Core State Standards.

${ }^{11}$ For the complete list of curricula followed by private schools in Ras Al Khaimah, see Appendix C
} 
Ras Al Khaimah has a network of charity schools, with approximately 2,000 students enrolled, funded by the government of Ras Al Khaimah and public donations. In these schools, students are taught by MOE teachers, who are paid through assistantships. With free enrollment, classes for the charity schools are taught in the evenings and adhere to the MOE curriculum with Arabic as the language of instruction. There are a total of 4 charity schools with 2 boys' schools and 2 girls' schools, with Cycle 1 and combined Cycle 2 and 3 branches for each gender (demographic details for the student population in Figure 13).

As Figure 13 shows, $68 \%$ of charity school enrolment is composed of Ras Al Khaimah residents with passports from the Comoros Islands, Egypt, Syria, and Yemen. About $40 \%$ of students are enrolled in Cycle 1 , and $60 \%$ in Cycle 2 and 3 respectively. There is a slight gender imbalance in enrolment as female students account for $56 \%$ of the student population and male students account for the remaining $44 \%$.

Figure 13: Enrollment in Charity Schools in Ras Al Khaimah by Nationality, Cycle, and Gender

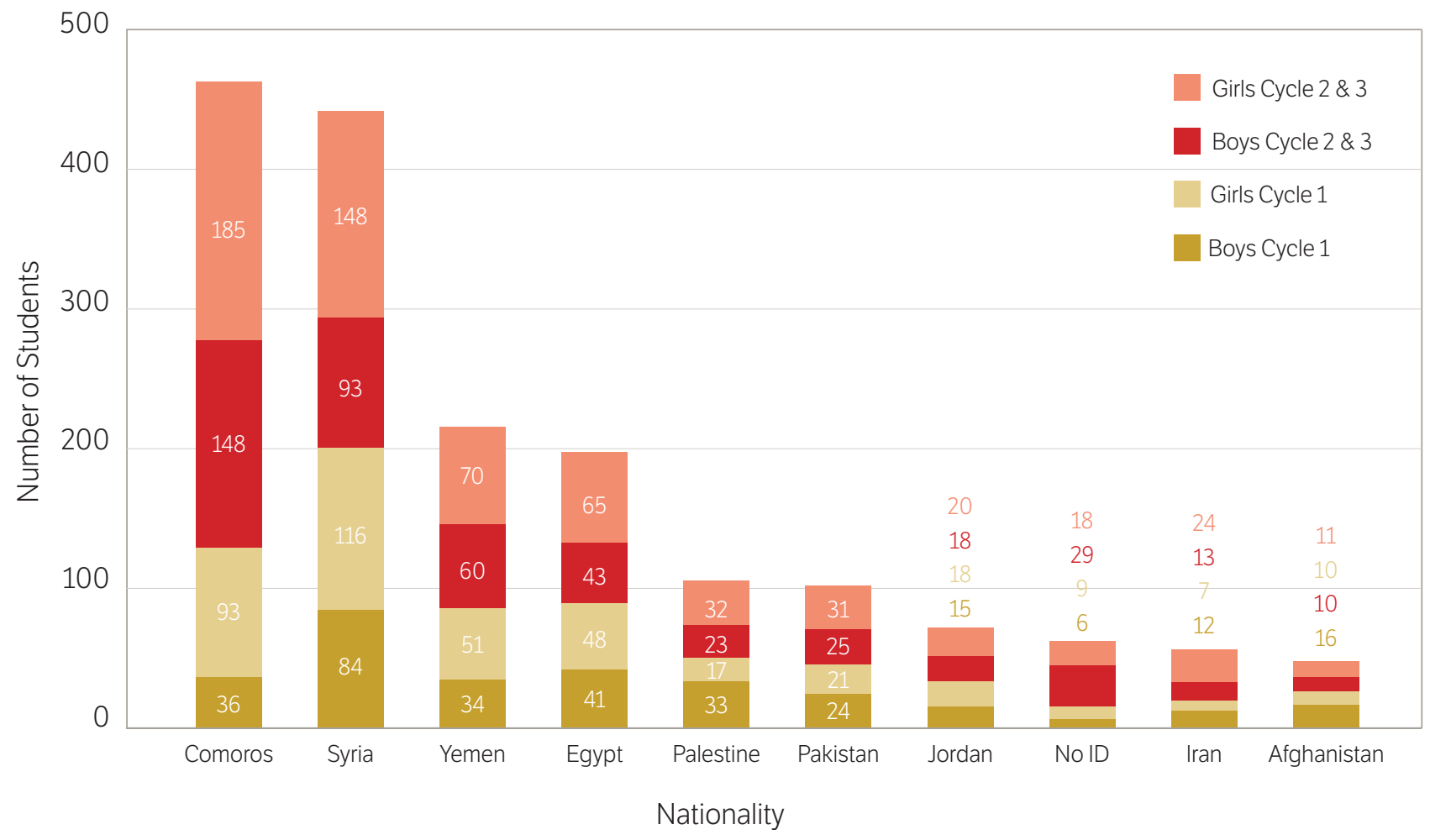

Source: Ras Al Khaimah Education Zone, 2020b $\mathrm{b}^{12}$

As Figure 13 shows, $68 \%$ of charity school enrolment is composed of Ras Al Khaimah residents with passports from the Comoros Islands, Egypt, Syria, and Yemen. About $40 \%$ of students are enrolled in Cycle 1 , and $60 \%$ in Cycle 2 and 3 respectively. There is a slight gender imbalance in enrolment as female students account for $56 \%$ of the student population and male students account for the remaining $44 \%$.

\footnotetext{
12 This graph charts the 10 most common nationalities. Other countries include Algeria, Bangladesh, China, India, Iraq, Lebanon, Libya, Mali, Morocco, Nigeria, Oman, Saudi, Somalia, Sudan, Tajikistan, Tunisia, Turkey, UAE.
} 


\section{Higher Education in Ras Al Khaimah}

There are approximately 4,800 students at 3 public higher education institutions and 2,000 students at 13 private higher education institutions located in Ras Al Khaimah (Ras Al Khaimah Economic Zone (RAKEZ), 2016b). These include the nationally accredited HCT men's and women's campuses, which are the only federal college in the emirate, as well as Ras Al Khaimah Medical and Health Sciences University and the American University of Ras Al Khaimah (AURAK) (Rensimer, 2015). Engineering/IT and Business make up approximately $90 \%$ of private enrollment, and together with Health and Medical Sciences constitute approximately 90\% of public enrollment as well (RAKEZ, 2016b). Between 2009 and 2013, the number of students enrolled in higher education in Ras Al Khaimah increased from 2,778 to 3,846 students (approximately $38 \%$ ), which was the second highest growth rate in the country over that period of time (Rensimer, 2015; UAE MOHESR, 2014). The majority of students in public universities are from Arab States while the majority in private higher education institutes is from South Asia (Figure 14).

Figure 14: Students at Public and Private Universities in Ras Al Khaimah, by Nationality

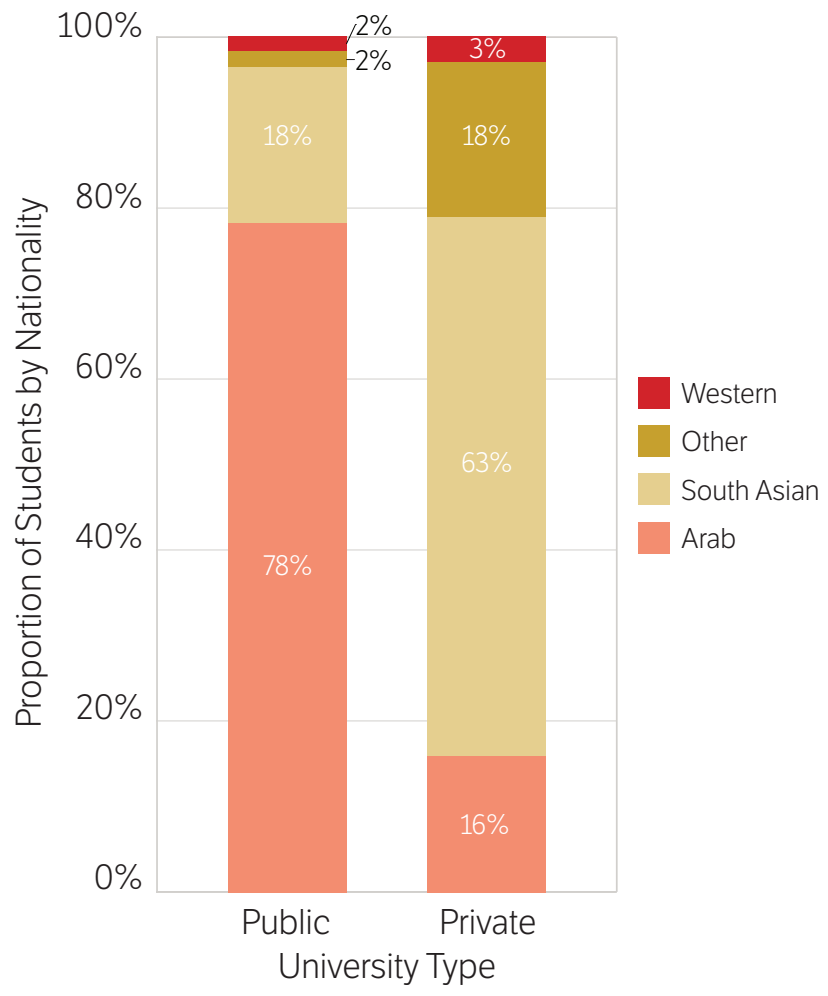

Source: Ras Al Khaimah Economic Zone (RAKEZ), 2016b
Ras Al Khaimah's university population reflects the wider gender disparity in higher education across the UAE, in which female university students considerably outnumber their male counterparts. During the 20192020 academic year there were 2,007 females enrolled at the HCT Ras Al Khaimah Women's College while there were only 481 men at the HCT Ras Al Khaimah Men's College, representing approximately a 4:1 ratio of women to men (See Box 4 for more information about gender disparity) (HCT, 2020).

\section{Gender Disparity in Educational Achievement in the UAE ${ }^{13}$}

A prominent characteristic of the UAE's education system is the reverse gender gap in favor of girls. While girls in the UAE not only surpass boys in terms of school enrollment, they also outperform them in terms of achievement (Ridge, 2014). This includes national assessments, where girls consistently outperform boys across the country. For example, on the 2014 Common Educational Proficiency Assessment (CEPA), girls scored an average of 168 points while boys scored an average of 163 points. However, the differences in favor of girls were more pronounced in certain geographical areas, such as in the Western Region, where girls scored an average of 160 points, while boys only scored an average of 135 points (AlHammadi, 2019). In 2017, the UAE introduced the Emirates Standardized Test (EmSAT), a series of computer-based tests which measures students' skills in Arabic, English, Maths, and Science replacing the Common Educational Proficiency Assessment (CEPA) as a national higher education entry requirement.

This gender gap pattern in favor of girls is observable on international assessments as well. Table B shows that girls in the UAE performed better than boys in all three PISA 2018 domains, with a 9-point difference in mathematics, 27-point difference in science, and 57-point difference in reading. This gender gap is even more pronounced for the UAE nationals as Emirati girls outperform Emirati boys by much wider margins compared to the aggregated national data, with a 72-point gap on reading scores. Within the larger context of PISA 2018, the UAE's performance gender gaps are some of the most significant gender differences observed in any PISAparticipating country (OECD, 2019).

\footnotetext{
${ }^{13}$ For even more information about the reverse gender divide in the UAE and wider Gulf region, see Education and the Reverse Gender Divide in the Gulf States: Embracing the Global, Ignoring the Local (Ridge, 2014).
} 
Table B: PISA 2018 Gender Comparison of Average Performance between the OECD and the UAE

\begin{tabular}{|c|c|c|c|c|c|c|}
\hline \multirow{2}{*}{ Subject } & \multicolumn{2}{|c|}{ OECD Average } & \multicolumn{2}{c|}{ All UAE Students } & \multicolumn{2}{c|}{ UAE Nationals } \\
\cline { 2 - 7 } & Male & Female & Male & Female & Male & Female \\
\hline Mathematics & 492 & 487 & 430 & 439 & 380 & 401 \\
\hline Science & 488 & 490 & 420 & 447 & 369 & 407 \\
\hline
\end{tabular}

Source: OECD, 2019

\section{Challenges and Opportunities}

Education in Ras Al Khaimah and across the UAE has made great progress since the introduction of formal education. Over the last several decades, the education system has undergone numerous reforms that have improved the quality of the education system and focused on supporting innovation and student success. Moving forward, there are still some areas that could benefit from continued focus, particularly in the public education sector.

The reverse gender gap (Box 4) presents an opportunity for growth by improving the academic performance of male Emirati students. This gender disparity, however, extends into the recruitment and retention of male Emirati teachers.

The wealth gap between Emiratis of high and low socioeconomic status (SES) is another area that would benefit from focused research and innovation. The effect of SES on academic achievement is reflected on international academic standards including PISA scores. In 2018, Emirati students in the highest wealth quintile consistently achieved higher scores in every subject up to a 60 point difference, controlling for gender and public/private school factors (Buckner, 2018).
Addressing the wealth gap includes fostering parental involvement, encouraging the entry of more non-profit schools into the private sector, and improving inclusive education and early childhood policies and practices.

There is opportunity for continued growth in evaluating and improving the public school curriculum to better meet the needs of society and the workplace. It is also of great importance to continue advancing and promoting research, particularly at the level of higher education, and incorporating scholarly contributions in government decisions and policies.

The UAE offers a range of education options available for both male and female students from the primary to university level, with public education at all levels provided for nationals free of charge. While much has been achieved, there are still areas that can continue to be strengthened to better serve students and their families. A deeper focus on certain areas, such as on curriculum evaluations as well as support for struggling Emirati boys, can help ensure that all students reach their potential. With continued research and the piloting of more education initiatives, the quality of education available to both citizens and residents of the UAE will continue to be enhanced. 


\section{Appendix A}

\section{Technical Education in the UAE: Abu Dhabi Centre for Technical \& Vocational Education and Training (ACTVET) ${ }^{14}$}

The Abu Dhabi Centre for Technical \& Vocational Education and Training (ACTVET) was established in 2010 under the directorate of His Highness General Sheikh Mohammed bin Zayed Al Nahyan (ACTVET, 2020a). ACTVET presently manages a number of secondary and tertiary level educational and vocational training programs, and it is accredited by the Vocational Education and Training Awards Council (ACTVET, 2020a). The aim of ACTVET is to "increase the number of skilled Emirati youth in rewarding career paths and foster life-long learning and personal development" (ACTVET, 2020a).

Two key organizations that fall under ACTVET are the Abu Dhabi Vocational Education and Training Institute (ADVETI) and the Institutes of Applied Technology (IAT). The main secondary school operations of these two entities were Secondary Technical Schools (STS) and Applied Technology High Schools (ATHS), as demonstrated in Figure A1.

Figure A1. Secondary Education Programs Overseen by ACTVET

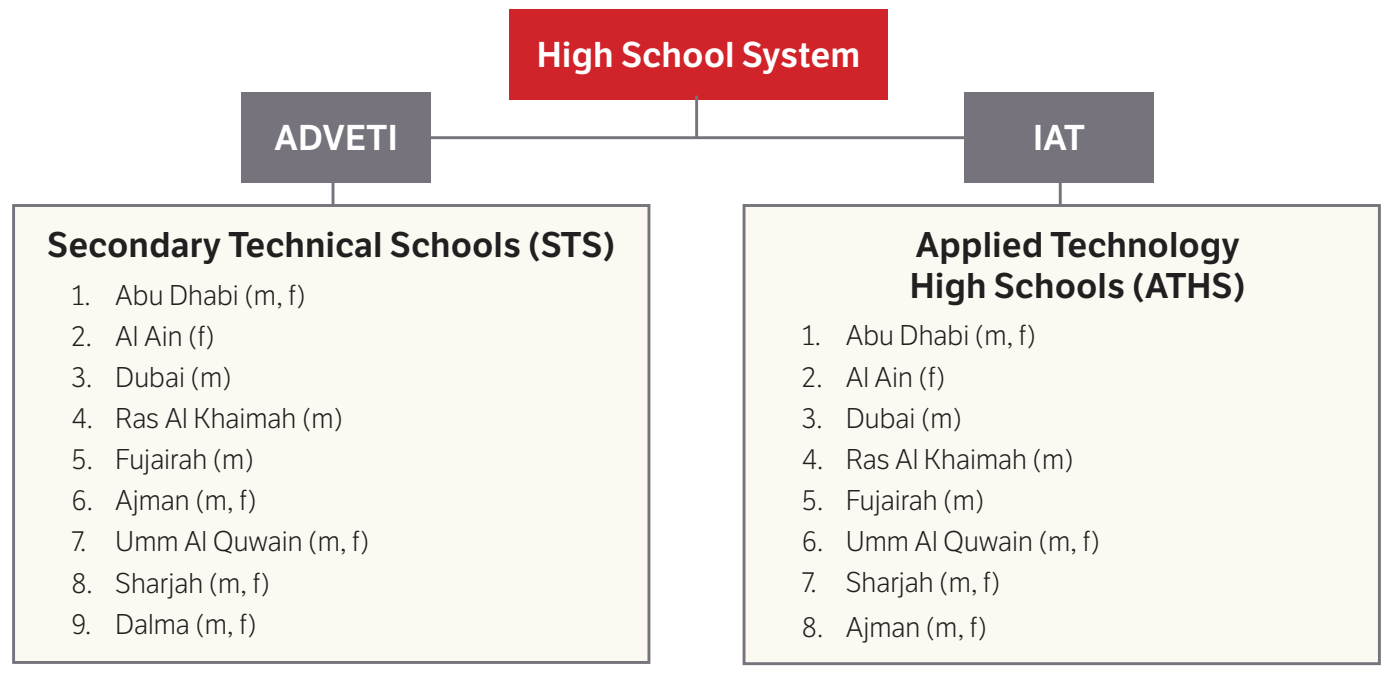

Note: $\mathrm{m}=$ male, $\mathrm{f}=$ female

Source: ACTVET, 2020c

Secondary Technical Schools (STS). ADVETI was created in 2007 as an initiative of the Abu Dhabi Government, with seven primary entities ${ }^{15}$ under it, including the Secondary Technical Schools (STS). The first STS school was piloted by ADVETI in 2010-11 in Abu Dhabi for male students, and it has since been expanded across the emirates. There were STS programs for both girls and boys, depending on the location (see Figure A1) (ATHS Directorate, 2019). STS runs a three-year program, beginning at Grade 10, designed to provide Emirati youth with a secondary school education centered on technical and technological education. Admission to STS is open to UAE nationals aged 14-16 who pass the STS entrance exams and meet other admission criteria (ATHS Directorate, 2019).

Applied Technology High Schools (ATHS). Founded in 2005 by the royal decree of His Highness Sheikh Khalifa bin Zayed Al Nahyan, the IAT operates as a "corporate body with full financial and administrative independence" (IAT, 2020b). The current Minister of Education, His Excellency Hussain Ibrahim Al Hammadi, has been Chairman of the Board of Trustees at IAT since its inception (IAT, 2020b). As part of its secondary education program, IAT runs Applied Technology High Schools (ATHS). Admission to ATHS requires an application and is open to UAE and GCC nationals who are 13-16 year olds and meet specific requirements (ATHS Directorate, 2019).

\footnotetext{
${ }^{14}$ For a more detailed overview of the wide-range of work led and overseen by ACTVET, see (ACTVET, 2020b).

15 These seven entities are Al Jazirah Institute of Science and Technology in Abu Dhabi, Al Jaheli Institute of Science and Technology in Al Ain, Baynounah Institute of Science and Technology in Western Region, Al Reef Institute of Logistics and Applied Technology in AI Shahama, Sharjah Institute of Science \& Technology in Sharjah, Secondary Technical School (STS), and Vocational Education Development Center (VEDC) (ADVETI, 2020a).
} 


\section{Appendix B}

\section{Emirates National Schools}

The Emirates National Schools (ENS) is a network of private schools that was started in 2002 under the auspices of the Ministry of Presidential Affairs. Currently, there are over 9,000 students enrolled across five ENS campuses in the UAE, three in Abu Dhabi, one in Sharjah, and one in Ras Al Khaimah. At the secondary level, classes are gender-segregated (ENS, 2016c).

English is the language of instruction for classes, except for Arabic and Islamic Studies, which are taught in Arabic (ENS, 2016a). For courses in Arabic, Islamic, and UAE Studies, ENS follows the educational requirements prescribed by the UAE Ministry of Education. However, for other courses, ENS follows the Common Core Standards and uses American curriculum content. Also, depending on the school, the ENS is authorized, or a candidate to become authorized, as an International Baccalaureate (IB) provider (ENS, 2016a). Grade 11 and 12 students can therefore sit for either the IB Diploma Programme (DP) or the College Board Advanced Placement Program (AP) (ENS, 2016c).

Admittance to ENS is open to students from any nationality (personal communication with ENS, 2016). The 2019-20 academic year fees in Abu Dhabi ranged from approximately 23,300 AED (USD 6,300) at the kindergarten level to 55,900 AED (USD 15,200) for Grade 12 (ENS, 2019).

\section{Appendix C}

\section{Curricula Followed by Private Schools in Ras Al Khaimah}

\begin{tabular}{|c|c|}
\hline Curriculum & School Name \\
\hline \multirow{12}{*}{$\begin{array}{l}\text { Ministry of } \\
\text { Education }\end{array}$} & Al Arabia School \\
\hline & Al Manar School \\
\hline & Al Mareidh Girls School \\
\hline & Al Nasr School \\
\hline & Al Rawaby Modern School \\
\hline & AI Salaf AI Saleh School \\
\hline & Dar AI Salam School \\
\hline & Islamic Education School \\
\hline & Nidaa Al Islam School \\
\hline & Ras Al Khaimah Modern School \\
\hline & $\begin{array}{l}\text { Sheikh Saud Bin Saqr Al Qasimi } \\
\text { Charitable School }\end{array}$ \\
\hline & Sheikha Hissa bint Saqr School \\
\hline \multirow{7}{*}{ Indian } & Alpha School \\
\hline & Delhi Private School \\
\hline & English Ideal School \\
\hline & Indian Private School \\
\hline & Indian Public High School \\
\hline & Indian Scholars School \\
\hline & New Indian School \\
\hline
\end{tabular}

\begin{tabular}{|c|c|}
\hline Curriculum & School Name \\
\hline \multirow{5}{*}{ British } & GEMS Westminster School \\
\hline & Harvest Private School \\
\hline & Ramsis English School \\
\hline & Ras Al Khaimah Academy \\
\hline & St. Mary’s High School \\
\hline \multirow{3}{*}{ American } & Emirates National School \\
\hline & $\begin{array}{l}\text { Ras Al Khaimah American Academy } \\
\text { for Girls }\end{array}$ \\
\hline & The WellSpring School \\
\hline $\begin{array}{l}\text { International } \\
\text { Baccalaureate }\end{array}$ & Ras Al Khaimah Private Academy \\
\hline Pakistani & Pakistan Secondary School \\
\hline Bangladeshi & Bangladesh English School \\
\hline SABIS & $\begin{array}{l}\text { The International School of } \\
\text { Choueifat }\end{array}$ \\
\hline
\end{tabular}

Source: Ras Al Khaimah Education Zone, 2020 


\section{Appendix D}

\section{Overview of Emirate-Level Regulatory Authorities}

\begin{tabular}{|l|l|l|}
\multicolumn{1}{c|}{ Emirate } & \multicolumn{1}{c|}{ Public } & \multicolumn{1}{c|}{ Private } \\
\hline Abu Dhabi & Abu Dhabi Education Zone & ADEK \\
\hline Al Dhafra Education Zone & \\
\hline Ajman & Ajman Education Zone & Ajman Education Zone \\
\hline Dubai & Dubai Education Zone & KHDA \\
\hline Fujairah & Fujairah Education Zone & Fujairah Education Zone \\
\hline Ras Al Khaimah & Ras Al Khaimah Education Zone & Ras Al Khaimah Education Zone \\
\hline Sharjah & Sharjah Education Council (KG) & \\
\hline Umm Al Quwain & Sharjah Education Zone (Cycle 1-3) & SPEA \\
\hline
\end{tabular}

Source: UAE Government, 2020j 


\section{References}

Abu Dhabi Centre for Technical and Vocational Education and Training (ACTVET). (2020a). Our Strategy. https://www.actvet.gov.ae/en/AboutUs/Pages/OurStrategy.aspx

Abu Dhabi Centre for Technical and Vocational Education and Training (ACTVET). (2020c). Education System:Overview. https://www.actvet.gov.ae/en/EducationSystem/Pages/Overview.aspx

Abu Dhabi Centre for Technical and Vocational Education and Training (ACTVET). (2020c). Education System: High School System. https://www.actvet.gov.ae/en/EducationSystem/Pages/HighSchoolSystem.aspx

Abu Dhabi Government (2020). TAMM: School Finder Tool. Retrieved on June 16, 2020. https://www.tamm. abudhabi/journeys/get-education/schools

Abu Dhabi Department of Education and Knowledge (ADEK). (2020a). Public Schools. https://www.adek. gov.ae/Education-System/Public-Schools

Abu Dhabi Department of Education and Knowledge (ADEK). (2020b). What we do. https://www.adek.gov. ae/About/What-we-do

Abu Dhabi Vocational Education Training Institute (ADVETI). (2020). Abu Dhabi Vocational Education Training Institute. https://www.adveti-re.ae/en/adveti

Alhammadi, M. A. (2019). Gender effects on leadership styles in public schools in Abu Dhabi, UAE [Doctoral dissertation, University of Glasgow]. http://theses.gla.ac.uk/41223/

Alhebsi, A., Pettaway, L. D., \& Waller, L. (2015). A history of education in the United Arab Emirates and Trucial Sheikdoms. The Global eLearning Journal, 4(1), 1-5. https://globalelearningjournal.files.wordpress. com/2010/11/a-history-of-education-in-the-united-arab-emirates-and-trucial-sheikdoms.pdf

AlNaqbi, A. (2009). The British educational policies in the Trucial States (1953-1971). Research Book Series. Ras Al Khaimah; United Arab Emirates (Arabic).

Applied Technology High School (ATHS) Directorate. (2019). Course Catalogue 2018-2019. Retrieved from http:// www.iat.ac.ae/downloads

Bahgat, G. (1999), Education in the Gulf monarchies: Retrospect and prospect. International Review of Education, 45(2), 127-136. http://dx.doi.org/10.1023/A:1003610723356

Brooks, R., Fuller, A., \&t Waters, J. L. (2012). Changing spaces of education: New perspectives on the nature of learning. Routledge.

Buckner, E. (2017). The Other Gap: Examining Low-Income Emiratis' Educational Achievement (Policy Paper No. 15). Sheikh Saud bin Saqr Al Qasimi Foundation for Policy Research. http://dx.doi.org/10.18502/aqf.0120

Commission for Academic Accreditation (CAA). (2020). Active institutions. https://www.caa.ae/caa/DesktopModules/ Institutions.aspx

Davidson, C. M. (2008). From traditional to formal education in the lower Arabian Gulf,1870-1971. Journal of History of Education Society, 37(5), 633-643. http://dx.doi org/10.1080/00467600701430020

Dubai Statistics Center. (2007). Students by education type and nationality. https://www.dsc.gov.ae/ Report/442227140SI04-01.pdf

Dubai Statistics Center. (2019). Enrolled students by education type and nationality. https://www.dsc.gov.ae/Report/ DSC_\%20SYB_2018_04\%20_01.pdf

Emirates National Schools (ENS). (2016a). Our Campuses. www.ens.sch.ae

Emirates National Schools (ENS). (2016b). Tuition \&t educational resource fees for 2016-2017. www.ens.sch. ae/admissions/fees-schedule/

Emirates National Schools (ENS). (2016c). Curriculum. www.ens.sch.ae/academics/curriculum-2/

Emirates National Schools (ENS). Tuition and educational resource fees for 2019-2020. https://www.ens.sch.ae/ uploads/Fees/ENS_Fees_20192020_ADC.pdf 
The Emirates Standardized Test (EmSAT). (2020). EmSAT - The Emirates Standardized Test. http://emsat. moe.gov.ae/emsat/default.aspx

Federal Competitiveness and Statistics Authority (FCSA). (2018a). Percentage of national students to non-national by emirate and sector. Retrieved from https://data.bayanat.ae/en_GB/dataset/percentage-of-nationalstudents-to-non-national-by-emirate-and-sector/resource/f80fbf3d-8e43-4c81-b646-616a59ceb3ec

Federal Competitiveness and Statistics Authority (FCSA). (2018b). National teachers in government education by education zone, stage, level and gender. Retrieved from https://data.bayanat.ae/en_ GB/dataset/government-education-national-teachers-by- education-zone-stage-level-and-gender

Federal Competitiveness and Statistics Authority (FCSA). (2018c). Number of students in higher education institutions by emirate \&t sector. https://data.bayanat.ae/en_GB/dataset/number-of-studentsin-higher-education-institutions-by-emirate-sector/resource/350d0add-f424-498b-a9dbb6635d89f4f4

Federal Competitiveness and Statistics Authority (FCSA). (2019a). Distribution of schools and classrooms, type of education by Emirate. Retrieved from https://data.bayanat.ae/en_GB/dataset/distributionof-schools-and-classrooms/resource/0ec21abe-e7b0-423c-9f13-9407b3f9d72d

Federal Competitiveness and Statistics Authority (FCSA). (2019b). Expat teachers in government education by education zone, stage, level and gender. Retrieved from https://data.bayanat.ae/en_GB/dataset/ government-education-expat-teachers-by-education-zone-stage-level-gender

Gray, A. (2017, Aug. 2). Parents in these places spend the most on their children's education. World Economic Forum. https://www.weforum.org/agenda/2017/08/parents-in-these-countries-spendthe-most-on-their-childrens-education/

Higher Colleges of Technology. (2016a). Colleges: Ras Al Khaimah Men's College; Ras Al Khaimah Women's College. http://www.hct.ac.ae/en/colleges/rkwc/

Higher Colleges of Technology. (2020). The Higher Colleges of Technology (HCT) fact book. http://www.hct. ac.ae/content/uploads/HCT-FACT-BOOK-2019-20.pdf

Institute of Applied Technology (IAT). (2020a). Schools: STS. http://www.iat.ac.ae/schools/sts

Institute of Applied Technology (IAT). (2020b). About IAT. http://www.iat.ac.ae/about-iat

Jonny, D. (2015, September 1). The (MOE) reclaims/brings back 38 schools from Madares AIGhad to public education sphere (Arabic). Al Ittihad Newspaper. http://www.alittihad.ae/details. php?id $=82499$ \&ty $=2015$ ctarticle $=$ full

Kamal, K., Ct Trines, S. (2018, August 10). Education in the United Arab Emirates. World Education News + Reviews. https://wenr.wes.org/2018/08/education-in the-united-arab-emirates

Khalifa University. (2020). Petroleum Institute. https://www.ku.ac.ae/institute/petroleum-institute/

Knowledge and Human Development Authority (KHDA). (2017). Higher education in Dubai. https:// www.khda.gov.ae/Areas/Administration/Content/FileUploads/Publication/Documents/ English/20170523085007_Dubai_Higher_Education_Guide.pdf

Knowledge and Human Development Authority (KHDA). (2019a). Curriculum requirements for private schools in Dubai for the academic year 2019/2020. https://www.khda.gov.ae/CMS/WebParts/TextEditor/Documents/ Curriculum_Requirements_for_Private_Schools_in_Dubai_Eng.pdf

Knowledge and Human Development Authority (KHDA). (2019b). Dubai School Inspection Bureau: Inspection key findings 2018-2019. https://www.edarabia.com/wp-content/uploads/2019/05/khda-generalreport-2018-19.pdf

Ministry of Education (MOE). (2011). Open data: School statistics 2010/2011. https://www.moe.gov.ae/Arabic/ Docs/2011-2012.pdf 
Ministry of Education (MOE). (2016). Open data: School statistics 2015/2016. Retrieved from https://www.gov.ae/En/ OpenData/Pages/ReportsAndStatistics.aspx

Ministry of Education (MOE). (2017). Public school teachers in the UAE 2017 (Arabic).

Ministry of Education (MOE). (2018). Open data: School statistics 2017/2018.

https://www.moe.gov.ae/Ar/OpenData/Documents/2017-2018.pdf

Ministry of Education (MOE). (2019). New licensure and accreditation standards for UAE higher education institutions as of September 2019. https://www.moe.gov.ae/En/MediaCenter/News/Pages/accreditation2.aspx

Ministry of Education (MOE). (2020a). Ministry of Education strategic plan 2017-2021. https://www.moe.gov.ae/En/ AboutTheMinistry/Pages/MinistryStrategy.aspx

Ministry of Education (MOE). (2020b). ASP elite stream. https://www.moe.gov.ae/en/importantlinks/forms/pages/ asp-elite-stream.aspx

Ministry of Education (MOE). (2020c). Applied stream. https://www.moe.gov.ae/en/importantlinks/forms/pages/ prostream.aspx

Ministry of Education (MOE). (2020d). Students and schools by type of education and gender in Ras Al Khaimah for the academic year 2019/2020.

Ministry of Finance. (2020). Federal Budget 2020. https://www.mof.gov.ae/en/resourcesAndBudget/fedralBudget/ Pages/budget2020.aspx

Nolan, L. (2012). Liberalizing Monarchies? How Gulf Monarchies Manage Education Reform (Brookings Doha Center Analysis Paper 4). https://www.brookings.edu/wp-content/uploads/2016/06/0229_ liberalizing_monarchies_eng.pdf

Organisation for Economic Co-operation and Development (OECD). (2019). PISA 2018 Results: Combined executive summaries volume I, II \& III. [Paris, France]: OECD Publishing. https://www.oecd.org/pisa/Combined_ Executive_Summaries_PISA_2018.pdf

Organisation for Economic Cooperation and Development (OECD). (2016). PISA 2015 Results (Volume l): Excellence and equity in education. PISA. Paris: OECD Publishing. http://dx.doi. org/10.1787/9789264266490-en

Pennington, R. (2016, October 17). Abu Dhabi education merger 'will strengthen research'. The National. www.thenational.ae/uae/abu-dhabi-education-merger-will-strengthen-research

PricewaterhouseCoopers (PWC). (2018). Understanding Middle East education: UAE country profile. https://www. pwc.com/m1/en/industries/education/publications/understanding-middle-east-education.pdf

Ras Al Khaimah Education Zone. (2015). RAK schools 2014-2015. (Arabic).

Ras Al Khaimah Education Zone. (2020a). Students and schools by type of education and gender in Ras Al Khaimah for the academic year 2019/2020. (Arabic).

Ras Al Khaimah Education Zone (2020b). Sheikh Saud bin Sagr Charitable Educational Foundation: Statistics of nationalities for the year 2019/2020.

Ras AI Khaimah Economic Zone (RAKEZ). (2016a). K-12 Landscape. [PowerPoint slides].

Ras AI Khaimah Economic Zone (RAKEZ). (2016b). Higher Education Landscape [PowerPoint slides].

Rensimer, L. (2015). International and commercial higher education in Ras Al Khaimah: Policies, problem areas, and promise (Policy Paper No. 15). Sheikh Saud bin Saqr Al Qasimi Foundation for Policy Research. http://dx.doi.org/10.18502/aqf.0035

Ridge, N., Shami, S., Kippels, S., \&t Farah, S. (2014). Expatriate teachers and education quality in the Gulf Cooperation Council (Policy Paper No. 11). Sheikh Saud bin Saqr Al Qasimi Foundation for Policy Research. http://dx.doi.org/10.18502/aqf.0029

Ridge, N. (2009). Privileged and penalized: The education of boys in the United Arab Emirates. (Doctoral dissertation). (UMI Number: 334836). Available at Teachers College, Columbia University. 
Ridge, N. (2014). Education and the reverse gender divide in the Gulf states: Embracing the global, ignoring the local. Teachers College Press.

Ridge, N. Y., Shami, S., \& Kippels, S. M. (2016). Private Education in the Absence of a Public Option: The Cases of the United Arab Emirates and Qatar. FIRE: Forum for International Research in Education, 3(2). Retrieved from http://preserve.lehigh.edu/fire/vol3/iss2/5

Ridge, N., Kippels, S., \& Farah, S. (2017). Curriculum development in the United Arab Emirates (Policy Paper No. 18). Sheikh Saud bin Saqr Al Qasimi Foundation for Policy Research. http://dx.doi.org/10.18502/aqf.0043

Ridge, N., Shami, S., \&t Kippels, S. (2017). Arab migrant teachers in the United Arab Emirates and Qatar: Challenges and opportunities. In Z. Barbar (Ed.), Arab Migrant Communities in the GCC. Hurst.

Ridge, N., Kippels, S., \&t ElAsad, S. (2017). Education in Ras Al Khaimah and the United Arab Emirates [Fact Sheet]. https://publications.alqasimifoundation.com/en/fact-sheet-education-in-the-united-arab-emirates-andras-al-khaimah

Rizvi, A. Ct Dajani, H. (2018, Sept 4). Exclusive: Mixed gender classes will 'curb bad behaviour' in UAE government schools. The National. https://www.thenational.ae/uae/education/exclusive-mixedgender-classes-will-curb-bad-behaviour-in-uae-government-schools-1.766814

Sharjah Private Education Authority (SPEA). 2020. About the authority. https://spea.shj.ae/en/pages/1117/ about-the-authority

Suliman, 0. M. (2009). A descriptive study of the educational system of the United Arab Emirates [Unpublished doctoral dissertation]. University of Southern California.

Swan, M. (2014, April 3). Emirati men prefer private universities. The National. https://www.thenational.ae/ uae/education/emirati-men-prefer-private-universities

Swan, M. (2016, August 10). UAE University to admit non-Emirati students for first time. The National. https://www.thenational.ae/uae/education/uae-university-to-admit-non-emirati-students-forfirst-time

The World Bank. (2016). Expenditure on education as per cent of total government expenditure. data. worldbank.org/indicator/SE.XPD.TOTL.GB.ZS

UAE Goverment. (2020a). Regulatory Authorities of Higher Education. https://u.ae/en/information-and-services/ education/higher-education/regulatory-authorities-of-higher-education

UAE Government. (2020b). Early childhood development and care. https://u.ae/en/information-and-services/socialaffairs/early-childhood-development-and-care

UAE Government (2020c). Admission to the UAE government schools. https://u.ae/en/information-and-services/ education/school-education-k-12/joining-k-12-education/admission-to-uae-government-schools

UAE Government. (2020d). Education for people of determination. https://u.ae/en/information-and-services/ education/education-for-people-with-specialneeds

UAE Government (2020e). Stages and streams of school education. https://u.ae/en/information-and-services/ education/school-education-k-12/joining-k-12-education/stages-and-streams-of-school-education

UAE Government. (2020f). Gender segregation. https://u.ae/en/information and-services/education/schooleducation-k-12/joining-k-12-education/gender-segregation

UAE Government. (2020g). Education 2020 strategy. https://u.ae/en/about-the-uae/strategies-initiatives-andawards/federal-governments-strategies-and-plans/education-2020-strategy

UAE Government (2020h). Future skills for youth. https://u.ae/en/information-and-services/jobs/future-skills-for-youth

UAE Government. (2020i). School fees. https://u.ae/en/information-and-services/education/schooleducation-k-12/joining-k-12-education/school-fees

UAE Government (2020j). Regulatory authorities of K-12 education. https://u.ae/en/information-andservices/education/school-education-k-12/regulatory-authorities-of-k-12-education 
UAE University. (2016a). Undergraduate admission. https://www.uaeu.ac.ae/en/admission/undergraduate_ admissions.shtml

UAE University. (2020). UAEU facts \&t figures. http://www.uaeu.ac.ae/en/about/facts_and_figures.shtml

UNESCO Institute of Statistics (UIS). (2020a). Education: Enrolment by Level of Education. Retrieved from http:// data.uis.unesco.org/

UNESCO Institue of Statistics (UIS).(2020b) Education: Number of inbound degree-seeking students in the UAE. Retrieved from http://data.uis.unesco.org/

UNESCO Institute of Statistics (UIS). (2020c). Education: Inbound internationally mobile students by region of origin. Retrieved from http://data.uis.unesco.org/

Zayed University. (2016a). About the university. https://www.zu.ac.ae/main/en/explore_zu/index.aspx

Zayed University. (2016b). Zayed University 2015-2016 factsheet. http://www.zu.ac.ae/main//files/ contents/open_data/zu_fact_sheet_2015_16.pdf

Zayed University. (2019). Fact book: 2018-2019. https://www.zu.ac.ae/main/files/contents/open_data/ factbook-2018-19.pdf

Zayed University. (2020). People of determination. https://www.zu.ac.ae/main/en/SASD/people-ofdetermination.aspx 


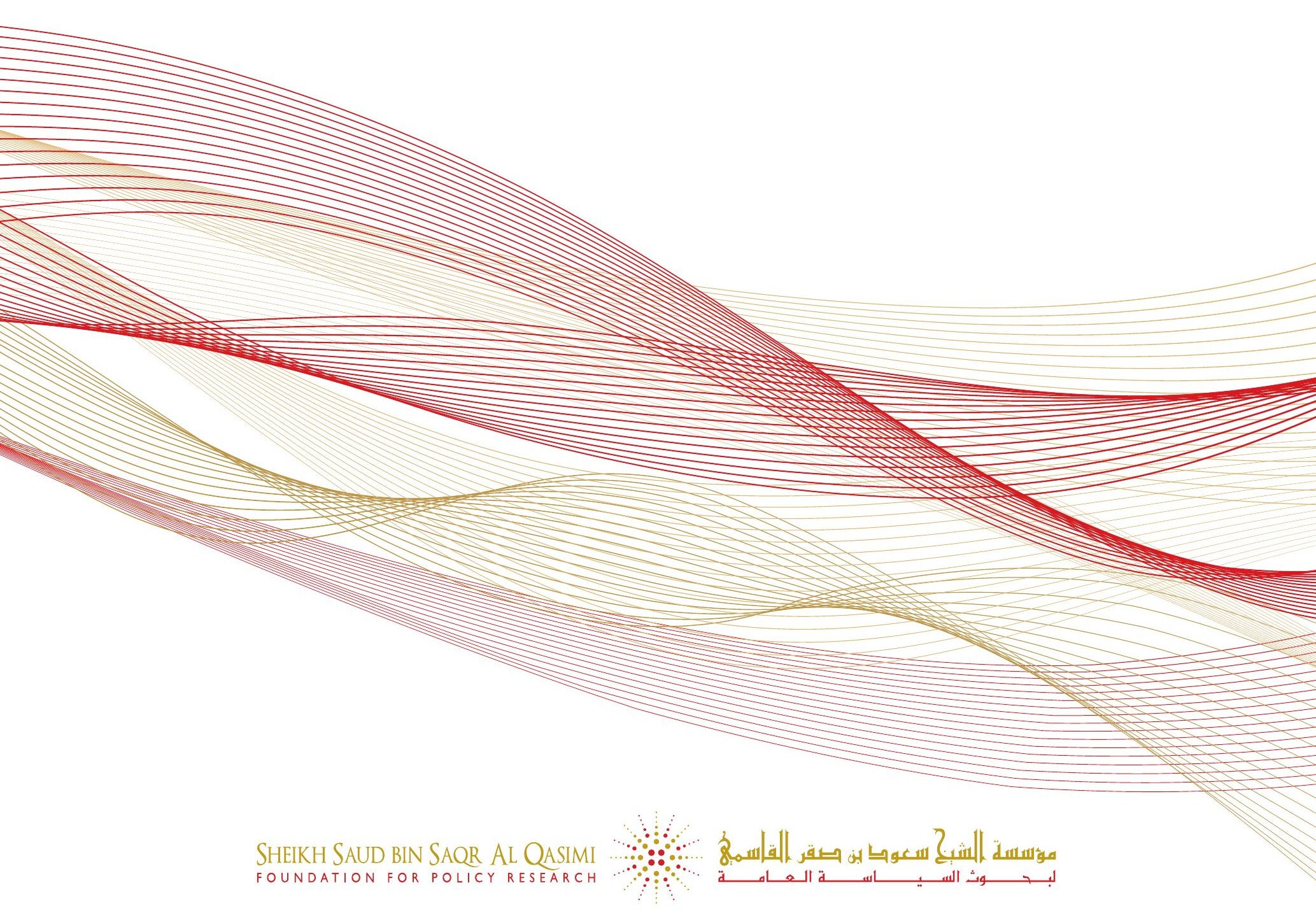

